\title{
PERFEKCIONISTA CSOPORTOK POZITÍV MENTÁLIS EGÉSZSÉGE - A PERFEKCIONIZMUS, AZ ÉRZELEMSZABÁLYOZÁS ÉS A SZUBJEKTÍV JÓLLÉT MINTÁZÓDÁSA FIATAL ÉLSPORTOLÓK KÖRÉBEN
}

\author{
REINHARDT MELINDA ${ }^{1,2}$ - TÓTH LÁSZLÓ³ - KENNETH G. RICE \\ ${ }^{1}$ ELTE Eötvös Loránd Tudományegyetem Pszichológiai Intézet \\ ${ }^{2}$ Zuglói Egészségügyi Szolgálat, Gyermek- és Serdülốpszichiátria \\ ${ }^{3}$ Testnevelési Egyetem, Gazdaság és Társadalomtudományi Intézet, \\ Pszichológia és Sportpszichológia Tanszék \\ ${ }^{4}$ Georgia State University, Department of Counseling and Psychological Services, \\ Center for the Study of Stress, Trauma, and Resilience, Atlanta, USA \\ E-mail: reinhardt.melinda@ppk.elte.hu \\ ORCID: https:/ / orcid.org/0000-0001-7010-5623
}

Beérkezett: 2019. augusztus 17. - Elfogadva: 2019. október 14.

Háttér és célkitûzések: A perfekcionizmus adaptív és maladaptív formái eltérố módon kapcsolódnak számos, az élsport terén alapvetố tényezôhöz (pl. teljesítmény, célorientáció). Vizsgálatunkban ezért a perfekcionista jellemzókön és az érzelemreguláció minöségén alapuló látens klaszterek azonosítását túztük ki célul serdülókorú élsportoló- és kontrollmintában. Feltártuk továbbá az egyes csoportok szubjektívjóllét-mutatóit is.

Módszer: 744 versenyszerüen sportoló középiskolást (60,2\% fiú, átlagéletkor $=16,83$ év, szórás =1,39) és 591 nem élsportoló osztálytársukat (50,8\% fiú, átlagéletkor $=16,91$ év, szórás $=1,65)$ vontuk be a felmérésbe. A kamaszok a következö három skála rövid változatát töltötték ki: Majdnem tökéletes skála (Rice és mtsai, 2014), Kognitív Érzelem-reguláció Kérdỗu (Garnefski és Kraaij, 2006) és Serdülō mentális egészség kontinuum skála (Keyes, 2006).

Eredmények: Látensprofil-elemzés segitségével mind az élsportoló-, mind a kontrollmintában egy jól interpretálható 3 osztályos megoldás körvonalazódott megfelelô illeszkedési mutatókkal. A kontrollcsoportban adaptív, maladaptív és nem perfekcionista profilok bontakoztak ki, ami számos korábbi teoretikus és empirikus eredménnyel egybecseng. Az élsportoló kamaszok körében nem perfekcionista csoportot nem tudunk azonositani. A maladaptív perfekcionisták maladaptív érzelemszabályozással csoport mellett a versenyszerüen sportolók körében az adaptív perfekcionisták két további osztályt épitettek fel: míg az egyik adaptív érzelemszabályozó stratégiákat képes mozgósítani, addig a másik adaptív perfekcionista csoport minimális mértékben alkalmaz kognitív érzelemregulációs folyamatokat. A hat látens osztály közül az adaptív perfekcionista élsportolók adaptív érzelemregulációval jellemezhetôk a legkiemelkedóbb szubjektívjóllét-szinttel mind a globális, mind az érzelmi, a pszichológiai és a társas well-beinget tekintve.

Következtetések: Rámutattunk arra, hogy az azonositott látens perfekcionizmus csoportok az érzelemszabályozás és a pozitív mentális egészség különbözô szintjeivel és mintázatával jellemezhetók.

Kulcsszavak: adaptív és maladaptív perfekcionizmus, kognitív érzelemreguláció, pozitív mentális egészség, élsportolók 


\section{BEVEZETÉS}

Fiatal élsportolók körében különösen fontos a perfekcionizmus és az azzal asszociálódó pszichés folyamatok felmérése és elemzése. A perfekcionizmus adaptív és maladaptív formája eltérô kapcsolatban van számos olyan jelenséggel, melyek lényeges szerepet játszanak a sportteljesítményben (pl. Stoeber, 2011; Hall, Jowett és Hill, 2014). Míg a magas belsố standardok, melyek az adaptív perfekcionizmus alapját képezik, facilitálni képesek a minél jobb teljesítményre törekvést, addig a perfekcionizmus maladaptív tényezôi, különösen az erôs önkritika, negatív érzelmi következményekhez és ezáltal gyengébb teljesítményhez vezethetnek (Gaudreau és Verner-Filion, 2012). A perfekcionizmus teljesítménygyengítô hatásának kiküszöbölése a sportolók, az edzôk és a sportpszichológusok számára is kihívás, egyben minden szakember érdeke és felelôssége az élsport terén.

\section{A vonásszintü perfekcionizmus mint multidimenzionális konstruktum}

A diszpozicionális perfekcionizmus olyan általános tendencia a személyiség múködésében, mely a tökéletességre törekvést és/vagy a személy saját magával kapcsolatos túlzott elvárásait foglalja magában (Flett és Hewitt, 2002). Ezek a túlzó elvárások egyaránt lehetnek a személy által saját maga számára kijelölt és/vagy a társas környezet által elôírt magas standardok vagy kiválósági mércék (Flett és Hewitt, 2006). A perfekcionizmus tehát egy összetett konstruktum, s a lelki múködés egyéb területeire kifejtett hatását jelentősen befolyásolja, hogy két nagy összetevője - (1) a magas standardok és (2) a túlzott, akár irreális elvárások - közül melyik dominánsabb (Terry-Short, Owens, Slade és Dewey, 1995). Amennyiben egyik perfekcionizmuskomponens sem aktív a személyiségszervezôdésben, úgy a perfekcionista beállítódás hiányáról (non-perfectionism) beszélünk (Rice és Ashby, 2007; Stoeber, 2012).

Korábban a perfekcionizmust monolit, egykomponensû jelenségként jellemezték, és csupán a negatív aspektusait emelték ki (pl. Burns, 1980). Hamachek (1978) nyomán azonban mára konszenzus alakult ki a szakirodalomban abban, hogy a perfekcionizmus egy többdimenziós konstruktum, és abban is, hogy ezek az összetevốk adaptív (pozitív, normál, pl. Hamachek, 1978; Andrews, Burns és Dueling, 2014) és maladaptív (negatív, neurotikus) perfekcionizmusformákat építenek fel (pl. Hamachek, 1978; Flett és Hewitt, 2002). A perfekcionista standardok (perfekcionista törekvések) azt jelentik, hogy a személy ragaszkodik a kiváló teljesítményhez, azaz a képességei magas fokon való kiteljesítéséhez. Mindent megtesz azért, hogy a tôle telhetô legjobbat nyújtsa, és a saját maga lehetôségeit kibontakoztassa, miközben figyelmét a pozitív kimenetekre fókuszálja. Ezzel szemben a perfekcionista elvárások azzal az intenzív vágygyal kapcsolódnak össze, hogy a személy szeretné elkerülni a hibázást. Az erôs félelem a kudarctól pedig a negatív megítéléstôl való fokozott szorongással párosul (Stoeber és Otto, 2006). A perfekcionista túlzott elvárásokat ezért gyakran perfekcionista aggodalmaknak is nevezik (Stoeber és Otto, 2006, 296). A szakirodalomban továbbá elterjedt a diszkrepancia elnevezés is a perfekcionizmus maladaptív formájának jelölésére. A diszkrepancia a személy saját magával kapcsolatos elvárásai és valós vagy lehetséges 
teljesítménye közötti távolságot jelenti. Ez a távolság minél nagyobb, annál magasabb szorongással, elégedetlenséggel, illetve önkritikával társul (Stoeber és Otto, 2006).

A perfekcionizmus adaptív és maladaptív formái a teljesítménnyel és a mentális egészséggel is különbözô módon kapcsolódnak össze. Az elôbbi a vizsgálatok szerint rendre jobb teljesítmény- és mentálisegészség-mutatókkal társul (pl. Andrews és mtsai, 2014), míg az utóbbi gyengébb teljesítménnyel és rosszabb lelki egészséggel, sốt pszichopatológiai jelenségekkel (pl. depresszív, szorongásos tünetekkel) jár együtt (pl. Stoeber, 2011; Rice, Richardson és Tueller, 2014). Hasonlóképpen, az adaptív és a maladaptív perfekcionizmus az adaptivitás tekintetében másféle érzelemszabályozási folyamatokkal kapcsolódik össze. Számos tudatos viselkedéses és kognitív stratégiát alkalmazhatnak az emberek, hogy érzelmeiket szabályozzák (Garnefski és mtsai, 2001). Ezek a kognitív érzelemszabályozási stratégiák segíthetik (adaptív érzelemregulációs technikák), de nehezíthetik is (maladaptív érzelemszabályozási módok) a helyzetekhez való alkalmazkodást (Garnefski és mtsai, 2001). Az adaptív perfekcionisták, mivel magabiztosabbak, és bíznak a sikerességükben, gyakrabban alkalmaznak problémafókuszú megküzdési módokat (pl. Burns és Fedewa, 2005) és adaptív érzelemszabályozási technikákat, például a helyzetek átértékelését (pl. Aldea és Rice, 2006). Ugyanakkor a kifejezettebb maladaptív perfekcionista vonások például a hibákkal kapcsolatos rumináció magasabb mértékével járnak együtt, ami a negatív érzelmek szabályozási deficitjéhez vezethet (pl. Frost és mtsai, 1997; Flett, Hewitt, Blankstein és Gray, 1998).

\section{A „perfekcionizmus paradoxon”- Adapatív és maladaptív perfekcionizmus a sportban}

Míg az adaptív perfekcionizmus olyan törekvésekkel jár, amelyek fokozzák a hatékonyságot, addig a maladaptív perfekcionizmus - vagy a magas belsô standardok mellett vagy az önmagában megjelenó állandó elégedetlenséggel, önkritikával - negatív érzelmi és teljesítménybeli következményekhez vezet (Rice, Richardson és Tueller, 2014).

A sport és az élsport terén is több olyan vizsgálat született, mely a fenti összefüggéseket igazolta. Az élsport területén végzett perfekcionizmuskutatások eredményeikben azonban kettôs arculatot mutatnak, attól függően, hogy a jelenség mely komponensét emelik ki. Dunn, Causgrove Dunn és Syrotuik (2002) például kanadai férfi labdarúgók 174 fôs mintáján vizsgálták a perfekcionista orientáció(k) és a sportolói célorientáció összefüggéseit. Eredményeik szerint, míg a feladatorientáció, azaz a feladat végrehajtására irányuló koncentráció a perfekcionizmus adaptív formájával járt együtt, addig az énorientáció a maladaptív perfekcionista jellemzókhöz asszociálódott a sport terén. Amennyiben tehát az énfókusz az uralkodó szemléletmód, maladaptív perfekcionista beállítódás igazolható. Mindez feltehetôen azzal lehet összefüggésben, hogy az erôs énfókusz megemelheti a perfekcionista aggodalmak és ezzel együtt más negatív érzések (pl. elégedetlenség, bû́ntudat, szorongás) szintjét, míg az erôs feladatfókusz az én, a személyes részvétel repetitív vizsgálata helyett a cél elérésére, a feladat jó színvonalú elvégzésére fókuszál, ami segíthet a magas személyes standardok adaptív fenntartásában. Ez egybecseng Hall, Kerr és Matthews (1998) eredményeivel: a magas feladatorientáció az adaptív perfekcionizmus egyetlen komponensével, a ma- 
gas személyes standardokkal volt kapcsolatban. Az extrém magas perfekcionizmussal jellemezhetô élsportolók mindent átható énorientált beállítódása debilizáló hatással járhat, amennyiben a képességeikkel kapcsolatban a személyeknek kétségeik támadnak (Flett és Hewitt, 2005). Fontos azonban kiemelni, hogy a bemutatott vizsgálatok egyike sem elemezte azokat a sportolói csoportokat, ahol mind a feladat-, mind az énfókusz magas vagy ellenkezôleg, alacsony volt.

Több kutatás, illetve áttekintô tanulmány is amellett érvel, hogy - bár a perfekcionizmus multidimenzionális konstruktum - az extrémen magas perfekcionizmus negatív következményekkel jár a versenysportban. Flett és Hewitt $(2005,14)$ a jelenséget a „perfekcionizmus paradoxona” címen tárgyalták. Kifejtették, hogy az élsportolóknak szükségük van arra a beállítódásra, hogy a lehetô legjobb teljesítményre törekedjenek, és arra a vágyra is, hogy hibázás nélkül érjék el a sikert. Ugyanakkor a perfekcionista személyiségvonások, a minden áron a legjobbra törekvés inkább aláássa a teljesítményt, és az azzal való elégedetlenség érzetét erôsíti, ami egyértelmúen negatív érzelmekkel és mentális állapottal társul. Ezt támasztja alá például Frost és Henderson (1991) kutatása: válogatott atlétanôk esetében a magas személyes perfekcionista standardok ugyan nem kapcsolódtak össze a versenyszorongással és az önbizalommal, azaz nem is rontották, de nem is javították ezeket a területeket, ugyanakkor ezeknek az atlétanôknek nehézséget jelentett a koncentráció a versenybemelegítés során, és erôteljesebben aggódtak a közönség reakciói miatt is. Ráadásul a magas személyes elvárások mind a siker-, mind a kudarcorientációval szignifikáns összefüggésben voltak, ami arra mutat rá, hogy azok az élsportolók, akik mindenáron igyekeznek magas személyes elvárásaiknak eleget tenni, fokozottan érzékenyek a másoktól származó pozitív és negatív visszajelzésekre.

Tovább árnyalják a képet olyan változók, mint az önértékelés, a sikerorientáció vagy a (sikeres) teljesítmény. Koivula, Hassme’n és Fallby (2002) például svéd élsportolók mintáján olyan perfekcionista személyeket azonosítottak, akiknek alacsony volt az önértékelésük, ráadásul az önbecsülésük erôsen függött a személyes elvárásaiktól. Ez a sportolói csoport nemcsak a hibázástól való félelem terén mutatott magas értékeket, hanem a személyes standardok terén is. A szerzốk szerint az ilyen kognitív múködésmóddal jellemezhetố versenyzôk számára a sikertelenség komoly fenyegetést jelent (Koivula és mtsai, 2002). Azt is fontos figyelembe venni, hogy a sportolóra milyen siker-, illetve kudarcmintázat jellemzô. Golfozók körében például a perfekcionizmus magas szintje a viszonylag sikeres játékosok körében nem kapcsolódott össze maladaptív vonásokkal és kimenetekkel, ugyanakkor a kevéssé sikeres golfozók esetében a magas perfekcionizmusszint a hibázással kapcsolatos negatív, diszfunkcionális gondolatokkal társult (Wieczorek, Flett és Hewitt, 2003). Fontos kérdés tehát, hogy a perfekcionista élsportoló rendelkezik-e azokkal a képességekkel, melyek az áhított végsố cél eléréséhez szükségesek, azaz céljai reálisak-e.

Azok a kutatók, akik a perfekcionizmust az élsportolói teljesítmény alapvetô minôségeként definiálják, a perfekcionizmusra jellemzó magas személyes standardokat állítják a vizsgálataik középpontjába (pl. Stoeber, 2011). Ezek a kutatók a perfekcionizmus ún. $2 \times 2$-es modelljét használják elméleti keretként (Gaudreau és Verner-Filion, 2012). A perfekcionizmus $2 \times 2$-es modellje (Gaudreau és Thompson, 2010) alternatív dimenzionális megközelítést kínál a perfekcionista csoportok azonosítására: csak 
azokat a személyeket azonosítja nem perfekcionistaként, akik mind a perfekcionista törekvések, mind a perfekcionista aggodalmak terén alacsony értékeket mutatnak. Azokat, akik alacsony perfekcionista törekvésekkel, de magas perfekcionista aggodalmakkal jellemezhetôk, „tisztán perfekcionista aggódóknak” tekinti, s egyértelmúen a maladaptív perfekcionisták csoportjába sorolja. Másrészt fontos szempontként tartják számon a perfekcionizmus „eredetét”, vagyis azt, hogy a perfekcionizmus a személy önmagával kapcsolatos elvárásaiból fakad-e, vagy a személy a társas környezet előírásaként éli-e meg. Sportolói mintán Gaudreau és Verner-Filion (2012) például kimutatták, hogy a sportolók saját magukkal szembeni magas elvárásszintje a szubjektív jóllét magasabb szintjével jár együtt.

Stoeber (2011) - ellentétben a Gaudreau és Thompson-féle (2010) felosztással, hasonlóan Rice és Ashby (2007) felfogásához - azt a csoportot is nem perfekcionistaként kategorizálja, amelyikben pusztán a perfekcionista aggodalmak kifejezettek. Érvelése szerint perfekcionizmus nem létezik magas személyes standardok nélkül. Stoeber (2011) áttekintésében számos olyan vizsgálatot felsorakoztat az élsport terén, amelyben a perfekcionista törekvések önmagukban pozitív mutatókkal társulnak. Amenynyiben a statisztikai elemzések során kontrollálták a két perfekcionizmus dimenzió átfedését, a magas perfekcionista törekvések önmagukban a sikeres sportteljesítményt követő fokozottabb pozitív érzelmeket (Sagar és Stoeber, 2009), valamint stabilabb önbizalmat és alacsonyabb kognitív, illetve szomatikus versenyszorongást jeleztek elôre (Stoeber, Otto, Pescheck, Becker és Stoll, 2007). Hasonlóképpen, az önmagában álló magas perfekcionista törekvések pozitívan kapcsolódtak a teljesítmény- és az énhatékonyság-központú célorientációhoz (Zarghmi, Ghamary, Shabani és Varzaneh, 2010), a sikerben való hithez és negatívan a hibázástól való félelemhez (Stoeber és Becker, 2008). Mindez arra mutat, hogy a perfekcionista törekvések jelentôs szerepet játszanak a sportmotivációban.

\section{Jelen vizsgálat célkitúzései}

A fenti összefoglalás rámutat arra a variabilitásra, mely a perfekcionizmus elméleti megalapozásában és kutatásában aktuálisan jelen van. Nincs ez másként az élsport területén sem, különösen amiatt, hogy a versenysportban a magas teljesítményelvárásoknak alapvetô szerepe van. A perfekcionista törekvések vélhetôen inkább a kiválóságra törekvés egészséges, pozitív formájával társulnak, ahogyan azonban az elméleti bevezetố is kiemelte, a kép nem egyértelmú.

Vizsgálatunk célja így tisztázni, illetve tovább árnyalni az eddigi eredményeket. (1) Részben azzal, hogy viszonylag nagy élsportoló serdülô mintán ( $\mathrm{N}=744)$ elemezzük a perfekcionizmus, a jóllét és az érzelemszabályozás kapcsolatát. Az eddigi vizsgálatok zöme alacsony mintaelemszámokkal dolgozott, ráadásul a felmérések gyakran csak az egyik nemre korlátozódtak. (2) Másrészt a kutatások alapvetốn változóorientált módszereket alkalmaztak, még akkor is, amikor kategoriális megközelítéssel perfekcionista csoportokat határoztak meg. Vizsgálatunkban látensprofil-elemzés segítségével mind az élsportoló, mind a kontrollserdülooket „természetes” csoportokba (látensen meglévő osztályokba) tudtuk sorolni a perfekcionizmusukra és érzelemszabályozásuk- 
ra vonatkozó önjellemzésük alapján, s ezeket a klasztereket értelmeztük. Ez a módszer és szemlélet lehetôvé teszi, hogy eredményeinket összehasonlítsuk az eddigi változóorientált elemzéseken alapuló kategóriákkal. (3) Harmadrészt célunk volt az is, hogy a kirajzolódó látens osztályokat a mentális egészség egyik komplex megközelítése, a Mentális Egészség Két-kontinuum Modellje (Two Continua Model of Mental Health vagy Dual-Continua Model of Mental Health, Keyes, 2002) alapján hasonlítsuk össze. A multidimenzionális modell a pozitív mentális egészséget az érzelmi, a pszichológiai és a szociális jóllét jellemzőiben, „tüneteiben” határozza meg (Oláh, 2012; Oláh és Kapitány-Fövény, 2012). Mivel a perfekcionizmus komplex jelenség, releváns célkitúzés annak vizsgálata, hogy annak egyes aspektusai milyen érzelemregulációs stratégiákkal és szubjektívjóllét-mutatókkal kapcsolódnak össze fiatal élsportoló mintán. Az eredmények a perfekcionizmus sportpszichológiai jövoobeni ellátását is árnyalhatják.

Hipotézisünk szerint mind az élsportoló-, mind a kontrollcsoportban a látens osztályelemzés módszerével is kirajzolódnak a perfekcionizmus kapcsán adaptív, maladaptív és nem perfekcionista csoportok, melyek a standardok és a diszkrepancia tekintetében eltérô mintázatot mutatnak. Feltételezzük továbbá, hogy az elemzéssel azonosított perfekcionista osztályok eltérô (globális, érzelmi, pszichológiai és szociális) jóllétszintekkel és érzelemszabályozási mintázattal írhatók le. Az elméleti bevezetôben bemutatott szakirodalmi eredményekre alapozva a legjobb jóllétmutatókat és a legtöbb adaptív érzelemszabályozó stratégia alkalmazását az adaptív perfekcionistáknál vártuk el. Eltérésre számítottunk továbbá ebben a mintázatban az élsportoló- és a kontrollcsoport között. A sportolást a mentális egészség szempontjából protektív faktorként azonosítva (Brady és Grenville-Cleave, 2018), feltételeztük, hogy a legkiválóbb jólléttel az adaptív perfekcionista élsportolók bírnak, és a legtöbb adaptív érzelemregulációs stratégiát is ók mozgósítják. Ezzel ellentétben a legrosszabb jóllét- és érzelemszabályozás-mutatókat a maladaptív perfekcionista kontrollcsoportnál vártuk.

\section{MÓDSZER}

\section{Minta}

A teljes mintát 1335 középiskolás fiatal alkotta. Átlagéletkoruk 16,87 év (szórás: 1,51 , terjedelem $=14-21$ év), 56\%-uk fiú, 44\%-uk pedig lány volt. A minta 55,7\%-a ( $\mathrm{N}=744)$ fiatal élsportolóból, míg 44,3\% ( N = 591) versenyszerú sporttevékenységet nem folytató, életkorban és osztályfokban illesztett kontrollcsoportból tevôdött öszsze. Élsportolónak, azaz versenyszerúen sporttevékenységet folytatónak az számított, aki (1) szervezett, egyesületi, szakszövetség által kidolgozott és ellenôrzött szabály- és versenyrendszer szerint úzi a sportágát, azaz sportegyesületnél igazolt versenyzô és részben az elôzóvel összefüggésben - (2) rendszeres sportorvosi ellenôrzés alatt áll. Az élsportolócsoport átlagéletkora 16,83 év (szórás = 1,39), míg a kontrollcsoport átlagéletkora 16,91 év (szórás = 1,65) volt. Az élsportolók 60,2\%-a fiú ( $\mathrm{N}=448)$, míg 39,8\%-a lány $(\mathrm{N}=296)$ volt. A kontrollcsoport 50,8\%-ban fiúkat $(\mathrm{N}=300)$ és 49,2\%-ban lányokat $(\mathrm{N}=291)$ foglalt magában. Az élsportoló- és a kontrollcsoport átlagéletkorában és 
a szülook közül az anya iskolai végzettségében nem mutatott szignifikáns különbséget. Eltérés mutatkozott azonban a két csoport nemi eloszlásában, ami összefüggésben áll azzal, hogy a serdülô korosztályban több fiú élsportoló található. Különbség volt kimutatható továbbá a két minta között az iskolai teljesítményben, az apák iskolai végzettségében, továbbá az életszínvonal és a fizikai egészség szubjektív megítélésének tekintetében, valamint a hétköznap és a hétvégén a számítógép elôtt töltött idô mértékében. Az élsportoló fiatalok kevésbé ítélik jónak iskolai teljesítményüket, és az apjuk között kisebb arányban fordul elô felsófokú végzettség. Ugyanakkor az élsportoló serdülôk a családjuk életszínvonalát és saját testi egészségüket összességében jobbnak véleményezték, és mind a hétköznapokon, mind pedig hétvégenként szignifikánsan kevesebbet használják a számítógépet, mint a nem élsportolók. Az élsportolómintában a legkülönfélébb sportágakban (pl. csapatsportokban és egyéni sportágakban, labdajátékokban, küzdôsportokban, vízi sportokban) versenyzó serdülốk találhatók. Az élsportoló fiatalok átlagosan 7 éves koruk óta sportolnak versenyszerúen $(\mathrm{M}=7,35 ; \mathrm{s}=$ 2,85; min. $=2$, max. $=15$ ). A minta alapadatait részletesen az 1. táblázat tartalmazza.

\section{Eszközök}

A kérdôívcsomagban az általános demográfiai és az élsportolók esetében a sportdemográfiai kérdések (pl. sportág, versenysportban eltöltött évek száma) mellett összesen hét kérdôív kapott helyet. Alább a jelen vizsgálat szempontjából releváns három mérốeszközt mutatjuk be.

\section{Majdnem tökéletes skála - rövid változat}

A Majdnem tökéletes skála rövidített változata (Short Almost Perfect Scale, SAPS; Rice és mtsai, 2014; a kérdőívet magyarra az eredeti szerzók engedélyével Reinhardt Melinda és Tóth László fordította 2016-ban) a vonásszintû perfekcionizmust és annak két jól elkülöníthetô - adaptív és a maladaptív - formáját méri fel. Két alskálája a Standardok (Törekvések), mely a magas személyes teljesítményelvárásokra utal és a Diszkrepancia, amely a személyes standardoktól való észlelt távolságot és az ezzel kapcsolatos aggodalmakat összegzi. Elóbbi skála a perfekcionizmus adaptív jellemzôit tükrözi, utóbbi az alkalmazkodást nehezítô jellegét. A teljes kérdôíven elérhetô minimumpontszám 8, míg a maximum 56 pont. A Standardok és a Diszkrepancia alskálákon egyaránt minimum 4, maximum 28 pont szerezhetô. A két alskála között az együtt járás a vizsgálatok alapján nem szignifikáns, bár fordított irányú (pl. Rice és mtsai, 2014; Reinhardt, Tóth és Rice, 2018). A 8 tételes önjellemzó mérôeszköz könnyen és gyorsan kitölthetô, fordított tétele nincs. A tételeket egy hétfokozatú Likert-típusú skálán kell értékelni 1-tôl (Egyáltalán nem értek egyet) 7-ig (Teljes mértékben egyetértek).

A skála pszichometriai szempontból kiváló mutatókkal bír: a magas reliabilitás- és validitáseredmények mellett a megerôsítô faktorelemzés (Factor mixture modeling, FMMs) és a látens klaszterezés is egy kétfaktoros (Standardok és Diszkrepancia) és háromosztályos (adaptív, maladaptív és nem perfekcionista csoportok) modellt tudott meg- 
1. táblázat. Az élsportoló- és kontrollminták leíró adatai

\begin{tabular}{|c|c|c|c|c|}
\hline & \begin{tabular}{|l} 
Teljes minta \\
$\mathrm{N}=1335$ \\
\end{tabular} & \begin{tabular}{|l|} 
Élsportolók \\
$\mathrm{N}=744$
\end{tabular} & $\begin{array}{l}\text { Kontroll } \\
\mathrm{N}=591\end{array}$ & $\begin{array}{l}\text { Statisztikai } \\
\text { próba értéke* }\end{array}$ \\
\hline Életkor (év), Átlag (szórás) & $16,87(1,51)$ & $16,83(1,39)$ & $16,91(1,65)$ & $\begin{array}{l}\mathrm{t}=1,01 \\
\mathrm{p}=0,314\end{array}$ \\
\hline \multicolumn{5}{|l|}{$\mathrm{Nem}, \%(\mathrm{~N})$} \\
\hline fiú & $56(748)$ & $60,2(448)$ & $50,8(300)$ & \multirow{2}{*}{$\begin{array}{l}\chi^{2}(1)=11,80 \\
p<0,001\end{array}$} \\
\hline lány & $44(587)$ & $39,8(296)$ & $49,2(291)$ & \\
\hline \multicolumn{5}{|l|}{$\begin{array}{l}\text { Anya iskolai végzettsége, \% } \\
(\mathrm{N})\end{array}$} \\
\hline felsôfokú & $46,6(618)$ & $45,3(334)$ & $48,1(284)$ & \multirow{6}{*}{$\begin{array}{l}\chi^{2}(4)=2,33 \\
p=0,676\end{array}$} \\
\hline középfokú & $35,9(476)$ & $36,5(296)$ & $35,1(207)$ & \\
\hline szakmunkás & $11,5(152)$ & $12,3(91)$ & $10,3(61)$ & \\
\hline általános & $1,4(19)$ & $1,5(11)$ & $1,4(8)$ & \\
\hline nem fejezte be az általánost & $0(0)$ & $0(0)$ & $0(0)$ & \\
\hline nem tudja & $4,7(62)$ & $4,3(32)$ & $5,1(30)$ & \\
\hline \multicolumn{5}{|l|}{ Apa iskolai végzettsége, \% (N) } \\
\hline felsôfokú & $39,4(525)$ & $34,8(258)$ & $45,2(267)$ & \multirow{6}{*}{$\begin{array}{l}\chi^{2}(5)=22,10 \\
p<0,001\end{array}$} \\
\hline középfokú & $27,8(370)$ & $27,9(207)$ & $27,6(163)$ & \\
\hline szakmunkás & $23,0(307)$ & $26,4(196)$ & $18,8(111)$ & \\
\hline általános & $1,4(19)$ & $2,0(15)$ & $0,7(4)$ & \\
\hline nem fejezte be az általánost & $0,2(2)$ & $0,1(1)$ & $0,2(1)$ & \\
\hline nem tudja & $8,3(110)$ & $8,8(65)$ & $7,6(45)$ & \\
\hline \multicolumn{5}{|l|}{ Iskolai teljesítmény, \% (N) } \\
\hline legjobb tanulók között & $11,8(157)$ & $11,7(87)$ & $11,9(70)$ & \multirow{4}{*}{$\begin{array}{l}\chi^{2}(3)=50,60 \\
p<0,0001\end{array}$} \\
\hline jó tanulók között & $41,6(555)$ & $33,7(251)$ & $51,5(304)$ & \\
\hline átlagos tanulók között & $43,3(577)$ & $51,3(382)$ & $33,1(195)$ & \\
\hline átlagnál rosszabb & $3,4(45)$ & $3,2(24)$ & $3,6(21)$ & \\
\hline \multicolumn{5}{|l|}{ Szubjektív életszínvonal, \% (N) } \\
\hline nagyon jómódú & $9,6(128)$ & $12,2(91)$ & $6,3(37)$ & \multirow{5}{*}{$\begin{array}{l}\chi^{2}(4)=27,00 \\
p<0,0001\end{array}$} \\
\hline elég jómódú & $39,3(525)$ & $40,9(304)$ & $37,4(221)$ & \\
\hline átlagos & $47,7(637)$ & $45,0(335)$ & $51,1(302)$ & \\
\hline nem jómódú & $3,0(40)$ & $1,6(12)$ & $4,7(28)$ & \\
\hline egyáltalán nem jómódú & $0,4(5)$ & $0,3(2)$ & $0,5(3)$ & \\
\hline \multicolumn{5}{|l|}{ Fizikai egészség, \% (N) } \\
\hline kitûnô & $34,5(460)$ & $45,0(334)$ & $21,3(126)$ & \multirow{4}{*}{$\begin{array}{l}\chi^{2}(3)=104,16 \\
p<0,0001\end{array}$} \\
\hline jó & $52,1(695)$ & $47,5(353)$ & $57,9(342)$ & \\
\hline megfelelő & $11,5(153)$ & $6,7(50)$ & $17,4(103)$ & \\
\hline rossz & $1,9(26)$ & $0,8(6)$ & $3,4(20)$ & \\
\hline $\begin{array}{l}\text { Számítógép hétköznap } \\
\text { (óra), Átlag (szórás) }\end{array}$ & $1,84(3,55)$ & $1,44(2,14)$ & $2,36(4,74)$ & $\begin{array}{l}\mathrm{t}=4,21 \\
\mathrm{p}<0,0001\end{array}$ \\
\hline $\begin{array}{l}\text { Számítógép hétvégén (óra), } \\
\text { Átlag (szórás) }\end{array}$ & $3,81(22,44)$ & $2,65(3,01)$ & $5,30(33,68)$ & $\begin{array}{l}\mathrm{t}=2,08 \\
\mathrm{p}=0,038\end{array}$ \\
\hline
\end{tabular}

Megjegyzés: *: Az élsportoló- és a kontrollcsoport összehasonlítása 
erôsíteni (Rice és mtsai, 2014). A mérôeszköz mind serdülố (Reinhardt és mtsai, 2018; Rice és mtsai, 2018), mind felnótt (Reinhardt, Rice és Tóth, 2019) magyar mintákon hasonlóan jó pszichometriai jellemzóket mutatott, mint az eredeti amerikai változat. A serdülőmintán a kérdốiv Cronbach-alfa-mutatója 0,85 volt (Reinhardt és mtsai, 2018).

\section{Kognitív Érzelem-reguláció Kérdőiv - rövid változat}

A Kognitív Érzelem-reguláció Kérdőív rövid formája (Short version of the Cognitive Emotion Regulation Questionnaire, CERQ-short; Garnefski és Kraaij, 2006) 18 tételbôl áll, megôrizve az eredeti kérdőív (Cognitive Emotion Regulation Questionnaire, CERQ; Garnefski és mtsai., 2001) 9 skáláját. A rövid változatban az egyes skálák már csak két-két tételt tartalmaznak. A méróeszköz azokat a kognitív folyamatokat térképezi fel, melyeket a személyek a stresszes élethelyzetekben kiváltódó érzelmeik szabályozására alkalmazhatnak. A kilenc skála közül öt adaptív érzelemregulációs stratégiákat mér fel: elfogadás; pozitív fókuszváltás; tervezés; átértékelés; perspektívába helyezés, míg négy skála az érzelemszabályozás maladaptív formáit méri: önvád; rumináció; katasztrofizálás; mások hibáztatása. Külön összegezhetôk az adaptív és nem adaptív alskálák, és megadható a teljes kérdôív összpontszáma is. Az összpontszám azt mutatja meg, hogy a válaszadó milyen mértékben múködtet a negatív érzelmei kezelésére figyelmi vagy gondolkodási folyamatokat (Miklósi, Martos, Kocsis-Bogár és Perczel Forintos, 2011). A kérdôív tételeit egy 5-fokú Likert-skálán értékelik a kitöltốk ( 1 = szinte soha és 5 = szinte mindig). Mind az eredeti hosszú (Garnefski és mtsai, 2001), mind pedig a rövid változat (Garnefski és Kraaij, 2006) pszichometriailag jól múködô skálák. A rövid változatot bevezetố tanulmányban (Garnefski és Kraaij, 2006) az egyes alskálák Cronbachalfa-mutatói 0,62 és 0,85 között változtak. A gyengébb reliabilitásmutatók összefüggésben állhatnak azzal, hogy az egyes alskálákat kevés, csupán két-két tétel építi fel. Az eredeti változat (CERQ) magyar adaptációja Miklósi és munkatársai (2011) munkája, melynek során a mérôeszköz hazai alkalmazhatóságát egyértelmúen alátámasztották. Ebben a vizsgálatban a reliabilitási adatok (Cr- $\alpha)$ 0,68 és 0,88 között változtak.

\section{Serdülố mentális egészség kontinuum skála - rövid változat}

A rövidített Serdülô mentális egészség kontinuum skála (Adolescent Mental Health Continuum-Short Form, Adolescent MHC-SF; Keyes, 2006, 2009) a mentális egészség pozitív aspektusainak felmérését célozza kamaszok körében. A szubjektív jóllétrôl globálisan és annak három nagy területérôl - az érzelmi, a pszichológiai és a szociális jóllétrôl - ad képet. A kitöltônek arra kell választ adnia, hogy az elmúlt egy hónapban a pozitív mentális egészség jellemzôit a saját megítélése szerint milyen gyakran tapasztalta önmagánál. A válaszok egy hatfokú skálán a $0=$ soha és az $5=$ minden nap között variálhatnak. A kérdôív összpontszáma minimum 0, maximum 70 lehet, a magasabb pontszám pozitívabb szubjektív jóllétet jelez. Fordított tételt a skála nem tartalmaz. Az összpontszám és a skálaátlagok számítása mellett ún. kategoriális besorolásra is lehetôség van, amikor a mentális egészség jellemzôinek megélési gyakoriságát vesz- 
szük alapul. Ennek alapján három kategóriába sorolhatjuk be a személyeket: virágzók, mérsékelt mentális egészséggel jellemezhetôk és hervadók (bóvebben lásd Reinhardt, 2014). A kérdôív kiváló pszichometriai mutatókkal rendelkezik (pl. Lamers, Westerhof, Bohlmeijer, Ten Klooster és Keyes, 2011). Magyar adaptációját Reinhardt (2013) végezte, melynek során magyar serdülôk mintáján is igazolta a kérdôív eredeti faktorstruktúráját és validitását, valamint kiváló reliabilitását (Cronbach-alfa a globálisjóllét-mutatón: 0,88, míg az egyes alskálákon: 0,72-0,83).

\section{Eljárás}

A keresztmetszeti kutatás keretében 2017 januárja és 2018 januárja között az összes olyan budapesti középiskolát felkértük a vizsgálatban való részvételre, amely sporttagozatos középiskolai tagozattal is rendelkezik, azaz ún. köznevelési típusú sportiskola. Ezekben az intézményekben az oktatást és a nevelést a sportoló fiatalok életvitelével igyekeznek összhangba hozni, így a kimagasló sportteljesítménnyel rendelkezô diákok esetében az iskola a sportoló egyesületével, illetve a szakszövetséggel szoros együttmúködésben egyéni tanrendet állít össze. Lényeges, hogy a legtöbb sportiskolában az élsportoló diákok mellett nem élsportoló tanulók is tanulnak - az adott iskola gyakorlatától függōen - vagy párhuzamos osztályokban, vagy az élsportolókkal vegyesen, egy osztályba járva. Ez a csoport alkotta mintánk kontrollját. A mintába minden középiskolai évfolyamból (9., 10., 11., 12. osztály) a sporttagozatos osztályt vagy osztályokat vontuk be, valamint minden évfolyamon - véletlenszerú sorsolással - a sporttagozatos osztály(ok) mellett futó egyik nem sporttagozatos osztályt.

Egy év leforgása alatt az adatfelvétel összesen 11 középiskolában zajlott le. Az iskolaigazgatók írásos engedélyüket adták az iskolában folytatott kutatáshoz. A kitöltést vállaló diákok a tesztfüzeteket a nevelési-oktatási intézményekben töltötték ki osztályfönöki óra keretében vagy nyomtatott formában, vagy - ahol lehetôség volt rá - az iskola számítógéptermében asztali számítógépen, online módon, internetes kérdôíves felületen keresztül. Az iskolák személyzete a vizsgálat egyik fázisában sem vett részt (sem a kérdôívek kiosztásában, sem a kitöltés felügyeletében, sem a tesztcsomagok beszedésében, illetve feldolgozásában).

A beérkezett kitöltésekbôl hiányos kitöltés miatt 36 fôt töröltünk az élsportolók közül, míg 23 fớt a kontrollcsoportból. Két-két fớt pedig azért vettünk ki a késóbbi elemzésekból, mert bizonyíthatóan nem vették komolyan a kitöltést (pl. minden kérdôívtételhez ugyanazt a számot írták be és/vagy vicces, esetenként trágár megjegyzéseket füztek azokhoz). Az eredeti 1398 fơs adatbázis így 1335 före csökkent.

\section{Statisztikai elemzés}

A mérőeszközök alapadatainak (skálaátlag és szórás) megadása mellett azokat független mintás t-próbával hasonlítottuk össze a két csoportban (élsportolók és kontroll). Az összefüggések erôsségét Cohen-d hatásméret-mutatóval (Cohen, 1992) becsültük. A kérdôívek belsố konzisztenciáját a Cronbach-alfa-mutatóval adtuk meg. 
Jelen tanulmány a hagyományos változóorientált megközelítés mellett ún. személyorientált elemzést - látensprofil-elemzést (Latent Profile Analysis, LPA) - is alkalmazott annak érdekében, hogy a teljes mintában, illetve mindkét vizsgált csoportban (élsportoló és nem élsportoló kontroll) a látensen meglévô, azaz a csoporttagok jellemzôibôl felépülő profilokat (Williams és Kibowski, 2015) térképezzen fel a perfekcionizmus és a jellemzően alkalmazott érzelemregulációs módok alapján. A perfekcionizmus két alskálája és az érzelemszabályozás kilenc módja esetében az átlag itempontszámokat folytonos indikátor változóként határoztuk meg. Az egyes látens profilokat ezt követôen egyszempontos ANOVA-val hasonlítottuk össze a globális szubjektív jóllét és annak elemei (érzelmi, pszichológiai és szociális jóllét) mentén. A szignifikanciaszintet minden esetben 95\%-os megbízhatósági szinten határoztuk meg.

Az elemzéseket az SPSS 25.0 és az Mplus 8.0 (Muthén és Muthén, 1998-2017) statisztikai szoftverekkel hajtottuk végre.

\section{Etikai vonatkozások}

A tanulmányban bemutatott kutatásra az Eötvös Loránd Tudományegyetem Pedagógiai és Pszichológiai Kar Kutatásetikai Bizottsága adott ki kutatásetikai engedélyt (száma: 2016/314). A kutatást a szerzốk a Helsinki nyilatkozat (WHO, 2001) etikai alapelveivel összhangban tervezték meg és hajtották végre. Ennek megfelelóen a tesztcsomagot csak azok a tanulók tölthették ki, akik korábban írásos informált beleegyezésüket adták a vizsgálatban való részvételükhöz. A részt vevô fiatalok szüleit passzív beleegyezésre kértük fel. A kérdốivcsomag kitöltése önkéntes alapon és névtelenül történt.

\section{EREDMÉNYEK}

\section{A vizsgálat alapstatisztikája}

A 2. táblázatban a felhasznált mérôeszközökhöz kapcsolódó alapstatisztikákat mutatjuk be. Mindhárom kérdôív belsố megbízhatósága teljesíti az elvárt szintet. A perfekcionizmus kérdôív (SAPS) és a Mentális egészség skála (MHC-SF) alskálái is megfelelố reliabilitásértékeket mutatnak, ahogyan a kognitív érzelemszabályozó módokat felmérô kérdôív (CERQ) adaptív és maladaptív érzelemreguláció-módokat összegzô skálái is. A CERQ kérdốiv egyes érzelemregulációs technikáit felmérô skálái közül kettô (CERQ Tervezés és Átértékelés) belsố konzisztenciája azonban minimálisan alatta marad az elvárt 0,70-es értéknek (Nunnually, 1978), ezért az evvel a két alskálával kapott eredményeket fokozott óvatossággal szükséges kezelni az értelmezés során.

Az egyes skálaértékek csoportátlagainak összehasonlításával elmondhatjuk, hogy a versenyszerú sporttevékenységet folytató serdülők szignifikánsan magasabb perfekcionizmusszinttel jellemezhetôk a kontrollcsoporthoz képest: mind a vonásszintû perfekcionizmust összességében, mind annak két összetevőjét (Standardok és Diszkrepancia) 
tekintve. Ugyanakkor meg kell említeni, hogy - a hatásméret-mutató (Cohen-d) alapján - a két csoport közötti különbség egyik esetben sem éri el a közepes hatásméretszintet, bár a Standardok esetében a statisztikai hatásméret valamivel kifejezettebb, itt markánsabban jelenik meg, hogy az élsportoló fiatalok átlagosan magasabb perfekcionista törekvésszinttel jellemezhetôk, mint a nem élsportoló társaik. Az érzelemszabályozás módjait tekintve kirajzolódik, hogy a nem élsportolók összességében több érzelemregulációs technikát alkalmaznak a negatív élethelyzeteik kezelésére (összesített CERQ-érték). Az adaptív technikák alkalmazási gyakoriságában nincs különbség (CERQ összesített adaptív stratégia érték), ugyanakkor a kontrollcsoport átlagosan valamivel több maladaptív érzelemregulációs módot alkalmaz (CERQ összesített maladaptív stratégia érték). Megjegyzendő, hogy a hatásméret igen alacsony, azaz a csoportok közötti különbség ugyan szignifikáns, de elenyészô. Amennyiben az egyes érzelemregulációs stratégiák mentén vizsgáljuk az érzelemszabályozásbeli különbségeket, láthatjuk, hogy az adaptív emócióregulációs módok közül a Tervezés és az Elfogadás területén, a maladaptívak közül pedig a Rumináció és a Katasztrofizálás esetében magasabb a használatuk a kontrollcsoport körében az élsportolókhoz képest. Ugyanakkor a különbség mértékét jelzô hatásméret-mutató ezekben az esetekben sem éri el a közepes szintet, a különbség mértéke kicsi. A szubjektív jóllét terén a kép egyértelmú: az élsportolók összjóllétszintje szignifikánsan magasabb a kontrollcsoporténál, ahogyan az egyes jóllétaspektusokban is magasabb értékeket érnek el, különösen a pszichés és a szociális jóllét terén. Itt a hatásméret-mutatók is megközelítik a közepes szintet.

\section{A látensprofil-elemzés eredményei}

Látensprofil-elemzés (Latent Profile Analysis, LPA) segítségével mind az élsportoló, mind a kontrollt alkotó kamaszok mintájában három jól elkülöníthetô osztály körvonalazódott. A látensprofil-elemzés illeszkedési mutatói a háromosztályos megoldás esetén megfelelőek voltak (3. táblázat), a három kirajzolódó klaszter pedig mindkét csoportban teoretikusan is jól értelmezhetô volt.

A versenyszerû sporttevékenységet nem folytató kontrollmintában a következô csoportok emelkedtek ki: (1) Az elsô csoportba olyan serdülók sorolódtak, akik kevesebb perfekcionista törekvéssel és kismértékú perfekcionista aggodalommal voltak jelle-

3. táblázat. A látensprofil-elemzés egyes modelljeinek illeszkedési mutatói

\begin{tabular}{|l|c|c|c|c|c|c|c|}
\hline Modell & $\begin{array}{c}\text { Best Log } \\
\text { Likelihood }\end{array}$ & $\begin{array}{c}\text { Free } \\
\text { parameters }\end{array}$ & BIC & AIC & cAIC & AWE & Entrópia \\
\hline 1. osztály & $-8341,56$ & 13 & 16776,60 & 16709,41 & 16789,60 & 16909,07 & - \\
\hline 2. osztály & $-8127,77$ & 22 & 16413,72 & 16300,32 & 16435,72 & 16637,90 & 0,86 \\
\hline 3. osztály & $\mathbf{- 8 ~ 0 1 1 , 2 7}$ & $\mathbf{3 1}$ & $\mathbf{1 6} \mathbf{2 4 5 , 4 4}$ & $\mathbf{1 6 ~ 0 8 6 , 0 8}$ & $\mathbf{1 6} \mathbf{2 7 6 , 4 4}$ & $\mathbf{1 6 5 6 1 , 3 2}$ & $\mathbf{0 , 8 0}$ \\
\hline 4. osztály & $-7934,21$ & 40 & 16156,02 & 15950,98 & 16196,02 & 16563,62 & 0,78 \\
\hline 5. osztály & $-7879,96$ & 49 & 15861,76 & 15861,76 & 16161,23 & 16611,54 & 0,80 \\
\hline
\end{tabular}

Megjegyzés: A legjobban illeszkedô és értelmezhetô modell vastaggal szedve. BIC = Bayesian Information Criteria; AIC = Akaike Infromation Criteria; $\mathrm{cAIC}=$ Consistent Akaike Infromation Criteria; AWE = Approximate Weight of Evidence Criterion. 
2. táblázat. A vizsgálatban szereplô skálák és alskálák megbízhatósági és leíró statisztikai mutatói és összehasonlításuk az élsportoló- és a kontrollcsoportban

\begin{tabular}{|c|c|c|c|c|c|c|}
\hline Változó & $\begin{array}{l}\text { Teljes minta } \\
N=1335 \\
\text { Átlag } \\
\text { (szórás) }\end{array}$ & $\begin{array}{c}\text { Élsportoló } \\
N=744 \\
\text { Átlag } \\
\text { (szórás) }\end{array}$ & $\begin{array}{l}\text { Kontroll } \\
N=591 \\
\text { Átlag } \\
\text { (szórás) }\end{array}$ & $\begin{array}{c}\text { A csoportok } \\
\text { összehasonlítása\# } \\
\text { t(df) }\end{array}$ & Cohen-d & $\operatorname{Cr}-\alpha$ \\
\hline SAPS össz. & $\begin{array}{l}39,46 \\
(9,37)\end{array}$ & $\begin{array}{l}40,99 \\
(8,62)\end{array}$ & $\begin{array}{l}37,51 \\
(9,91)\end{array}$ & $\mathrm{t}_{(1318)}=6,70 * * *$ & 0,37 & 0,85 \\
\hline $\begin{array}{l}\text { SAPS } \\
\text { Standardok }\end{array}$ & $\begin{array}{l}22,03 \\
(5,04)\end{array}$ & $\begin{array}{l}22,95 \\
(4,54)\end{array}$ & $\begin{array}{l}20,86 \\
(5,39)\end{array}$ & $\mathrm{t}_{(1321)}=7,49 * * *$ & 0,42 & 0,86 \\
\hline $\begin{array}{l}\text { SAPS } \\
\text { Diszkrepancia }\end{array}$ & $\begin{array}{l}17,43 \\
(5,73) \\
\end{array}$ & $\begin{array}{l}18,04 \\
(5,49)\end{array}$ & $\begin{array}{l}16,65 \\
(5,92)\end{array}$ & $\mathrm{t}_{(1320)}=4,36^{* * *}$ & 0,24 & 0,77 \\
\hline CERQ össz. & $\begin{array}{c}50,57 \\
(10,90) \\
\end{array}$ & $\begin{array}{r}49,75 \\
(10,85) \\
\end{array}$ & $\begin{array}{c}51,60 \\
(10,87) \\
\end{array}$ & $\mathrm{t}_{(1303)}=3,06^{* *}$ & 0,17 & 0,84 \\
\hline CERQ Adaptív & $\begin{array}{l}30,31 \\
(7,30)\end{array}$ & $\begin{array}{l}30,04 \\
(7,23)\end{array}$ & $\begin{array}{l}30,65 \\
(7,38)\end{array}$ & $\mathrm{t}_{(1305)}=1,52$ & 0,08 & 0,82 \\
\hline CERQ Maladaptív & $\begin{array}{l}20,27 \\
(5,99) \\
\end{array}$ & $\begin{array}{l}19,73 \\
(5,93) \\
\end{array}$ & $\begin{array}{l}20,96 \\
(5,99) \\
\end{array}$ & $\mathrm{t}_{(1312)}=3,70 * * *$ & 0,21 & 0,80 \\
\hline CERQ Elfogadás & $\begin{array}{c}6,41 \\
(2,12)\end{array}$ & $\begin{array}{c}6,28 \\
(2,06)\end{array}$ & $\begin{array}{c}6,59 \\
(2,18)\end{array}$ & $\mathrm{t}_{(1314)}=2,64 * *$ & 0,15 & 0,81 \\
\hline $\begin{array}{l}\text { CERQ Pozitív } \\
\text { fókuszváltás }\end{array}$ & $\begin{array}{c}5,14 \\
(2,27) \\
\end{array}$ & $\begin{array}{c}5,16 \\
(2,29) \\
\end{array}$ & $\begin{array}{c}5,11 \\
(2,25) \\
\end{array}$ & $\mathrm{t}_{(1311)}=0,40$ & 0,02 & 0,81 \\
\hline CERQ Tervezés & $\begin{array}{c}6,60 \\
(1,99) \\
\end{array}$ & $\begin{array}{c}6,49 \\
(1,94) \\
\end{array}$ & $\begin{array}{c}6,74 \\
(2,06) \\
\end{array}$ & $\mathrm{t}_{(1312)}=2,28^{*}$ & 0,12 & 0,65 \\
\hline CERQÁtértékelés & $\begin{array}{c}6,42 \\
(2,06) \\
\end{array}$ & $\begin{array}{c}6,42 \\
(2,03) \\
\end{array}$ & $\begin{array}{c}6,42 \\
(2,10) \\
\end{array}$ & $\mathrm{t}_{(1311)}=0,02$ & 0 & 0,64 \\
\hline CERQ Perspektíva & $\begin{array}{c}5,74 \\
(2,11) \\
\end{array}$ & $\begin{array}{c}5,68 \\
(2,09) \\
\end{array}$ & $\begin{array}{c}5,83 \\
(2,14) \\
\end{array}$ & $\mathrm{t}_{(1313)}=1,25$ & 0,07 & 0,72 \\
\hline CERQ Önvád & $\begin{array}{c}5,43 \\
(2,07) \\
\end{array}$ & $\begin{array}{c}5,35 \\
(2,00) \\
\end{array}$ & $\begin{array}{c}5,54 \\
(2,16) \\
\end{array}$ & $\mathrm{t}_{(1313)}=1,64$ & 0,09 & 0,71 \\
\hline CERQ Rumináció & $\begin{array}{c}6,26 \\
(2,28) \\
\end{array}$ & $\begin{array}{c}5,96 \\
(2,15) \\
\end{array}$ & $\begin{array}{c}6,63 \\
(2,39) \\
\end{array}$ & $\mathrm{t}_{(1313)}=5,31 * * *$ & 0,29 & 0,83 \\
\hline $\begin{array}{l}\text { CERQ } \\
\text { Katasztrofizálás }\end{array}$ & $\begin{array}{c}4,41 \\
(2,17) \\
\end{array}$ & $\begin{array}{c}4,25 \\
(2,10) \\
\end{array}$ & $\begin{array}{c}4,60 \\
(2,24) \\
\end{array}$ & $\mathrm{t}_{(1314)}=2,84 * *$ & 0,16 & 0,82 \\
\hline $\begin{array}{l}\text { CERQ Mások } \\
\text { hibáztatása }\end{array}$ & $\begin{array}{c}4,18 \\
(1,85) \\
\end{array}$ & $\begin{array}{c}4,18 \\
(1,85) \\
\end{array}$ & $\begin{array}{c}4,18 \\
(1,85) \\
\end{array}$ & $\mathrm{t}_{(1314)}=0,03$ & 0 & 0,76 \\
\hline MHC össz. & $\begin{array}{c}44,78 \\
(11,90) \\
\end{array}$ & $\begin{array}{r}46,69 \\
(11,04) \\
\end{array}$ & $\begin{array}{c}42,37 \\
(12,51) \\
\end{array}$ & $\mathrm{t}_{(1324)}=6,57 * * *$ & 0,37 & 0,88 \\
\hline $\begin{array}{l}\text { MHC } \\
\text { Érzelmi jóllét }\end{array}$ & $\begin{array}{c}10,30 \\
(3,20) \\
\end{array}$ & $\begin{array}{l}10,60 \\
(2,92) \\
\end{array}$ & $\begin{array}{c}9,93 \\
(3,47) \\
\end{array}$ & $\mathrm{t}_{(1332)}=3,75^{* * *}$ & 0,21 & 0,84 \\
\hline $\begin{array}{l}\text { MHC } \\
\text { Pszichés jóllét }\end{array}$ & $\begin{array}{l}21,17 \\
(5,67) \\
\end{array}$ & $\begin{array}{l}22,07 \\
(5,16) \\
\end{array}$ & $\begin{array}{l}20,02 \\
(6,04) \\
\end{array}$ & $\mathrm{t}_{(1329)}=6,56^{* * *}$ & 0,36 & 0,80 \\
\hline $\begin{array}{l}\text { MHC } \\
\text { Társas jóllét }\end{array}$ & $\begin{array}{l}13,32 \\
(5,11)\end{array}$ & $\begin{array}{l}14,01 \\
(4,99)\end{array}$ & $\begin{array}{l}12,45 \\
(5,13)\end{array}$ & $\mathrm{t}_{(1328)}=5,59 * * *$ & 0,31 & 0,72 \\
\hline
\end{tabular}

Megjegyzés: $* p<0,05 ; * *<0,01 ; * * * p<0,0001$. \#: Az élsportoló- és a kontrollcsoport összehasonlítása. A hatásméret-mutató (Cohen-d) értékeit Cohen (1992) alapján az alábbiak szerint értelmeztük: 0,20: kis hatás, 0,50: közepes hatás, 0,80: nagymértékú hatás. Cr- $\alpha=$ Cronbach- $\alpha$.

SAPS = Short Almost Perfect Scale, Majdnem tökéletes skála rövidített változata; CERQ = CERQ-short, Cognitive Emotion Regulation Questionnaire-short; Kognitív Érzelem-reguláció Kérdốiv rövid formája. MHC = Adolescent Mental Health Continuum-Short Form, Serdülô mentális egészség kontinuum skála. 
mezhetôk. Öket nem perfekcionista csoportnak neveztük el, a teljes minta 29\%-át tették ki $(\mathrm{N}=171)$. Az ebbe a csoportba tartozók nagyon kevés érzelemregulációs stratégiát alkalmaztak a negatív helyzetek kezelésére, legyen az adaptív vagy maladaptív kognitív érzelemszabályozó stratégia $(\mathrm{NKN}=$ nem perfekcionista kontroll kevés érzelemszabályozó stratégiával). (2) A kontrollkamaszok közel fele $(41 \% ; \mathrm{N}=236$ ) a második látens csoportba került. Ôk magasabb perfekcionista standardokkal, de alacsonyabb perfekcionista aggodalmakkal rendelkeztek, azaz adaptív perfekcionista vonásokat mutattak. Ennek a csoportnak a tagjai jellemzóen adaptív érzelemregulációs folyamatokat alkalmaztak (AKA = adaptív perfekcionista kontroll adaptív érzelemregulációval). Ugyanakkor megjegyzendő, hogy a maladaptív érzelemregulációs módok közül a ruminációértékük ugyan alacsonyabb volt, mint a harmadik, ún. maladaptív csoporté, de magasabb, mint a nem perfekcionistáké. Az adaptív perfekcionista csoport is alkalmazza bizonyos mértékben a rágódást mint helyzetkezelô kognitív stratégiát a mindennapi stresszes szituációkban. (3) A harmadik csoportba tartozók (30\%; $\mathrm{N}=172$ ) bírtak a legmagasabb perfekcionista standardokkal, amihez a legmagasabb perfekcionista aggodalmak társultak. Ôket egyértelmúen maladaptív perfekcionistáknak nevezhetjük. Ez a csoport jellemzôen maladaptív érzelemszabályozási stratégiákat használt, kifejezetten magas önvád-, rumináció- és katasztrofizálásértékekkel (MKM = maladaptív perfekcionista kontroll maladaptív érzelemregulációval). Fontos azonban azt is kiemelni, hogy körükben közepes mértékben a pozitív érzelemregulációs technikák alkalmazása is megjelent a negatív helyzetek kezelésében: ezek mozgósításában az adaptív és a nem perfekcionista csoportok között helyezkedtek el. A tervezés és a helyzetek elfogadása tekintetében megközelítették vagy el is érték az adaptív perfekcionista csoport átlagértékeit. Ami viszont alig jelent meg a körükben, az a pozitív fókuszváltás. Nehezebben képesek tehát a negatív szituációkban figyelmüket a megnyugtató, pozitív gondolatokra terelni. Kiemelendô, hogy a mások hibáztatása mint helyzetkezelô mód egyik perfekcionista csoportra sem volt jellemzô (1. ábra).

A versenyszerúen sportoló fiatalok esetében (2. ábra) a maladaptív perfekcionista csoport maladaptív érzelemszabályozással (MÉM) egyértelmúen kirajzolódott (23\%; $\mathrm{N}=176$ ). Az élsportoló kamaszok maladaptív perfekcionista látens osztályára is jellemzô volt a magas perfekcionista standardok és a magas diszkrepancia (azaz a standardok és a teljesítmény között észlelt távolság) együttes jelenléte. Lényeges azonban, hogy ez a csoport - a kontroll hasonló maladaptív osztályával ellentétben - ugyanolyan mértékben alkalmazott pozitív érzelemregulációs stratégiákat, mint az adaptív perfekcionista, adaptív érzelemregulációval jellemezhetô élsportolócsoport (AÉA). A maladaptív érzelemregulációs módok (önvád, rumináció és katasztrofizálás) alkalmazásában azonban elváltak az adaptív perfekcionistáktól: az alkalmazkodást zavaró kognitív és figyelmi helyzetkezelési eszközök kifejezettebbek a maladaptív csoportban.

Fontos eredmény, hogy az élsportolók körében „eltûnt” a nem perfekcionista csoport. A fennmaradó két csoport ugyanis a perfekcionizmus két aspektusa (magas standardok, alacsonyabb diszkrepancia) tekintetében nem különbözött egymástól. Míg az egyik csoportban (52\%; $\mathrm{N}=381$ ) jellemzó volt az adaptív érzelemregulációs stratégiák használata a maladaptív érzelemreguláció alacsony szintje mellett, addig a másik csoportban $(25 \% ; \mathrm{N}=181)$ általában nagyon alacsony volt mind az adaptív, mind a maladaptív kognitív érzelemszabályozási módok használata. Mindkét csoport adaptív 


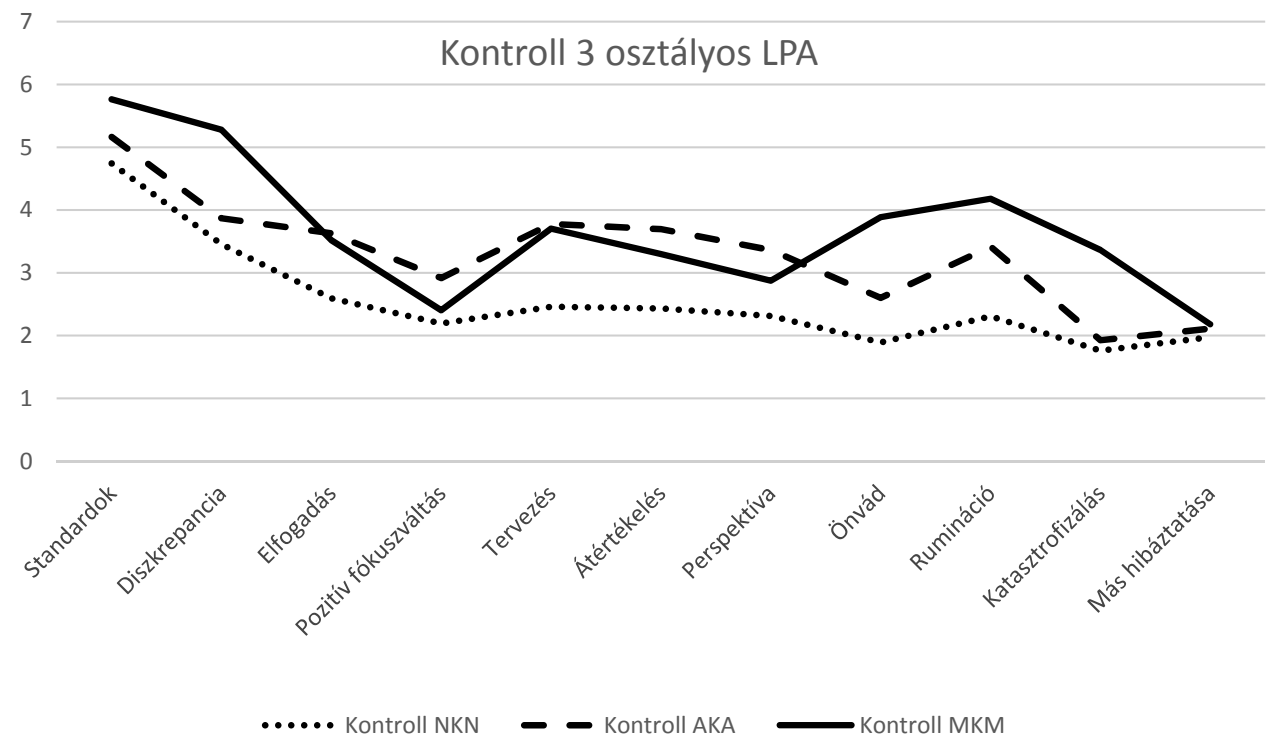

1. ábra. Látens perfekcionizmus és érzelemreguláció profilok a kontrollcsoportban

Megjegyzés: $\mathrm{NKN}=$ nem perfekcionista kontroll kevés érzelemszabályozó stratégiával; AKA = adaptív perfekcionista kontroll adaptív érzelemregulációval; $\mathrm{MKM}$ = maladaptív perfekcionista kontroll maladaptív érzelemregulációval; LPA = látensprofil-elemzés.

\section{Élsportolók 3 osztályos LPA}

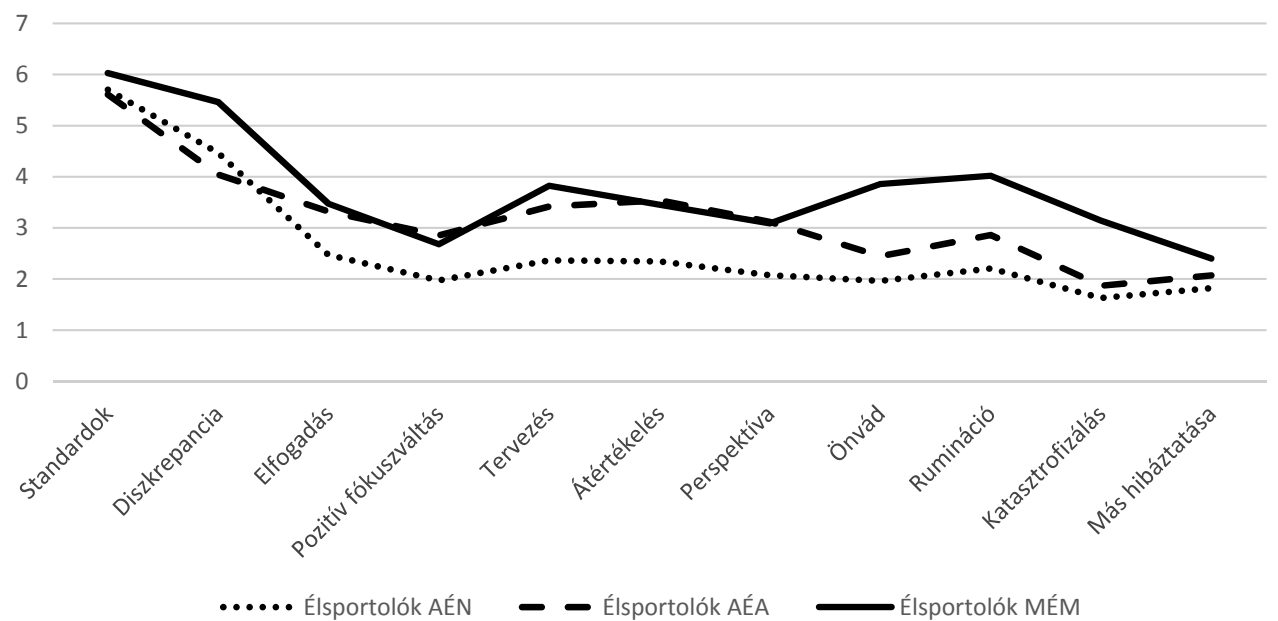

2. ábra. Látens perfekcionizmus és érzelemreguláció profilok az élsportolók mintájában

Megjegyzés: AÉN = adaptív perfekcionista élsportolók, akik kevéssé alkalmaznak érzelemszabályozó módokat; AEA = adaptív perfekcionista élsportolók adaptív érzelemszabályozási technikákkal; MÉM = maladaptív perfekcionista élsportolók maladaptív érzelemregulációval; LPA = látensprofil-elemzés. 
perfekcionista jellemzókkel bír, de az egyiknél ezek adaptív érzelemreguláció mozgósításával párosulnak, a másiknál nem, vagy nagyon kevéssé. Az elóbbi csoportnak „adaptív perfekcionista élsportolók adaptív érzelemregulációval” (AÉA), az utóbbinak pedig az „adaptív perfekcionista élsportolók kevés érzelemszabályozó stratégiával” (AÉN) címkét adtuk.

Összességében tehát hat látens osztály rajzolódott ki. A hat látens osztály leíró statisztikai eredményeit a 4. táblázat tartalmazza.

4. táblázat. A hat látens osztály leíró statisztikai adatai

\begin{tabular}{|c|c|c|c|c|c|c|c|c|c|c|c|c|}
\hline & 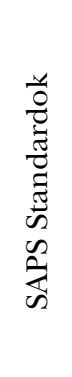 & 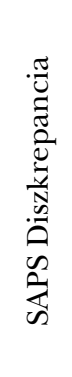 & 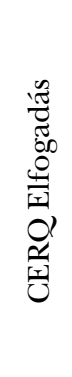 & 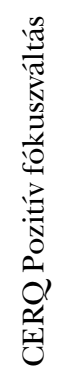 & 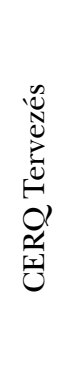 & 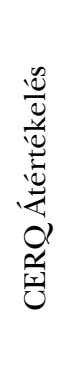 & 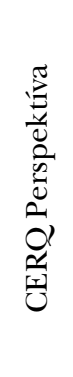 & 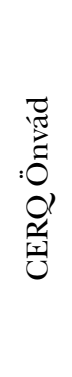 & 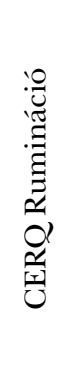 & 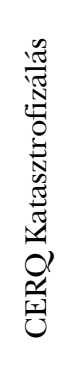 & 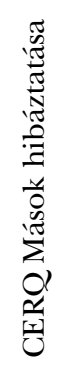 \\
\hline & & \multicolumn{11}{|c|}{ Az egyes skálákon elért átlagpontok* } \\
\hline \multirow{3}{*}{ Kontroll } & 1. AKA & 5,17 & 3,87 & 3,63 & 2,92 & 3,78 & 3,70 & 3,37 & 2,60 & 3,42 & 1,93 & 2,11 \\
\hline & 2. NKN & 4,74 & 3,46 & 2,60 & 2,19 & 2,46 & 2,43 & 2,31 & 1,89 & 2,31 & 1,76 & 1,98 \\
\hline & 3. MKM & 5,76 & 5,28 & 3,52 & 2,40 & 3,71 & 3,30 & 2,88 & 3,89 & 4,18 & 3,36 & 2,18 \\
\hline \multirow{3}{*}{$\begin{array}{l}\text { Él- } \\
\text { sportolók }\end{array}$} & 1. AÉA & 5,61 & 4,04 & 3,32 & 2,86 & 3,42 & 3,54 & 3,12 & 2,45 & 2,86 & 1,87 & 2,07 \\
\hline & 2. AÉN & 5,71 & 4,47 & 2,47 & 1,97 & 2,37 & 2,35 & 2,08 & 1,96 & 2,21 & 1,63 & 1,82 \\
\hline & 3. MÉM & 6,03 & 5,46 & 3,47 & 2,68 & 3,82 & 3,45 & 3,09 & 3,86 & 4,02 & 3,14 & 2,40 \\
\hline
\end{tabular}

Megjegyzés: *Az egyes skálák átlagait a könnyebb átláthatóság érdekében leosztottuk a skálákhoz tartozó tételek számával.

AÉA = adaptív perfekcionista élsportolók adaptív érzelemszabályozási technikákkal; AÉN = adaptív perfekcionista élsportolók, akik kevéssé alkalmaznak érzelemszabályozó módokat; MÉM = maladaptív perfekcionista élsportolók maladaptív érzelemregulációval; AKA = adaptív perfekcionista kontroll adaptív érzelemregulációval; $\mathrm{NKN}$ = nem perfekcionista kontroll kevés érzelemszabályozó stratégiával; MKM = maladaptív perfekcionista kontroll maladaptív érzelemregulációval; SAPS = Short Almost Perfect Scale, Majdnem tökéletes skála rövidített változata. CERQ = CERQ-short, Cognitive Emotion Regulation Questionnaire-short; Kognitív Érzelem-reguláció Kérdôív rövid formája.

\section{A látensprofil-elemzéssel kapott csoportok összehasonlítása szubjektív jóllétük tekintetében}

A fentebb bemutatott 3 élsportoló és 3 kontroll látens csoportot összehasonlítottuk a szubjektív jóllétük alapján. Figyelembe vettük mind a teljes, globálisjóllét-mutatót, mind a jóllét három (érzelmi, pszichológiai és társas) aspektusát (lásd Keyes, 2002). A legkiválóbb pozitív mentális egészséggel azok az élsportolók jellemezhetôk, akiknél az adaptív perfekcionista mintázat adaptív érzelemregulációval társult (AÉA). Ez a csoport szignifikánsan különbözött mindegyik másik csoporttól. Őket az adaptív perfekcionista kontrollcsoport (AKA) és az adaptív perfekcionista, de kevés érzelemsza- 
bályozó mechanizmust alkalmazó élsportolók (AÉN) követték. A nem perfekcionista kontroll (NKN) és a maladaptív perfekcionista atléták (MÉM) nem különböztek jelentôsen szubjektív jóllétük tekintetében. A legrosszabb mentálisegészség-átlaggal a maladaptív perfekcionista kontrollok (MKM) bírtak. Az eredményeket részletesen az 5. táblázat foglalja össze.

Amennyiben a pozitív mentális egészséget felépítő három jóllétterületet külön-külön vizsgáljuk, a pszichés jóllét tekintetében a globális jóllét kapcsán kapott eredményeket látjuk viszont. Az érzelmi jóllétben azonban nem mutatható ki különbség az adaptív perfekcionista adaptív érzelemregulációval bíró élsportolók (AÉA) és az adaptív perfekcionista kontroll (AKA) között. A legrosszabb emocionális jólléttel itt is a maladaptív kontrollperfekcionisták (MKM) bírtak. A társas jóllét dobogóján az adaptív perfekcionista élsportolók (AÉA) álltak, míg a maladaptív perfekcionista kontrollcsoport (MKM) ebben a jóllétaspektusban is sereghajtó volt. Mindennek áttekintését az 5. táblázat tartalmazza.

5. táblázat. A 2×3 látens osztály összehasonlítása a pozitív mentális egészség tekintetében

\begin{tabular}{|c|c|c|c|c|c|c|c|c|}
\hline 足 & 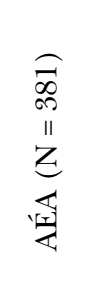 & 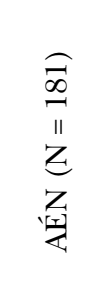 & 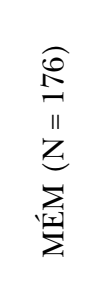 & 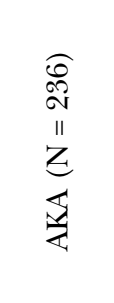 & $\begin{array}{l}\widehat{I} \\
\\
Z \\
Z \\
Z \\
Z \\
Z\end{array}$ & 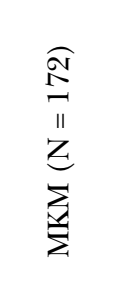 & 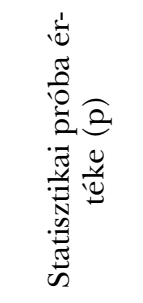 & 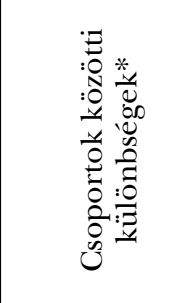 \\
\hline $\begin{array}{l}\text { MHC } \\
\text { össz }\end{array}$ & $\begin{array}{l}49,88 \\
(9,24)\end{array}$ & $\begin{array}{c}44,15 \\
(11,58)\end{array}$ & $\begin{array}{c}42,37 \\
(11,92)\end{array}$ & $\begin{array}{c}46,22 \\
(10,38)\end{array}$ & $\begin{array}{c}42,96 \\
(12,11)\end{array}$ & $\begin{array}{c}36,49 \\
(13,52)\end{array}$ & $\begin{array}{l}\mathrm{F}=38,40 \\
(<0,0001)\end{array}$ & $\begin{array}{l}\text { AÉA }>\text { AKA = } \\
\text { AÉN }>\text { NKN = } \\
\text { MÉM }>\text { MKM }\end{array}$ \\
\hline $\begin{array}{l}\text { MHC } \\
\text { Érzelmi } \\
\text { jóllét }\end{array}$ & $\begin{array}{l}11,31 \\
(2,51)\end{array}$ & $\begin{array}{l}10,32 \\
(2,95)\end{array}$ & $\begin{array}{c}9,36 \\
(3,26)\end{array}$ & $\begin{array}{l}10,85 \\
(2,78)\end{array}$ & $\begin{array}{l}10,43 \\
(3,43)\end{array}$ & $\begin{array}{c}8,18 \\
(3,77)\end{array}$ & $\begin{array}{l}\mathrm{F}=30,24 \\
(<0,0001)\end{array}$ & $\begin{array}{l}\text { AÉA }=\text { AKA > } \\
\text { AÉN }=\text { NKN > } \\
\text { MÉM }>\text { MKM }\end{array}$ \\
\hline $\begin{array}{l}\text { MHC } \\
\text { Pszichés } \\
\text { jóllét }\end{array}$ & $\begin{array}{l}23,63 \\
(4,39)\end{array}$ & $\begin{array}{l}20,86 \\
(5,17)\end{array}$ & $\begin{array}{l}19,94 \\
(5,61)\end{array}$ & $\begin{array}{l}21,87 \\
(5,17)\end{array}$ & $\begin{array}{l}20,16 \\
(5,61)\end{array}$ & $\begin{array}{l}17,27 \\
(6,60)\end{array}$ & $\begin{array}{l}\mathrm{F}=39,36 \\
(<0,0001)\end{array}$ & $\begin{array}{l}\text { AÉA }>\text { AKA = } \\
\text { AÉN }>\text { NKN = } \\
\text { MÉM }>\text { MKM }\end{array}$ \\
\hline $\begin{array}{l}\text { MHC } \\
\text { Társas } \\
\text { jóllét }\end{array}$ & $\begin{array}{l}14,92 \\
(4,48)\end{array}$ & $\begin{array}{l}12,99 \\
(5,55)\end{array}$ & $\begin{array}{l}13,10 \\
(5,10)\end{array}$ & $\begin{array}{l}13,56 \\
(4,68)\end{array}$ & $\begin{array}{l}12,35 \\
(5,09)\end{array}$ & $\begin{array}{l}11,04 \\
(5,44)\end{array}$ & $\begin{array}{l}F=16,78 \\
(<0,0001)\end{array}$ & $\begin{array}{l}\text { AÉA }>\text { AKA }= \\
\text { AÉN }=\mathrm{NKN}= \\
\text { MÉM }>\text { MKM }\end{array}$ \\
\hline
\end{tabular}

Megjegyzés: *A jelzett csoportok közötti különbségek minimum $\mathrm{p}<0,05$ szinten szignifikánsak.

MHC = Adolescent Mental Health Continuum-Short Form, Serdülő mentális egészség kontinuum skála; AÉA = adaptív perfekcionista élsportolók adaptív érzelemszabályozási technikákkal; AÉN = adaptív perfekcionista élsportolók, akik kevéssé alkalmaznak érzelemszabályozó módokat; MÉM = maladaptív perfekcionista élsportolók maladaptív érzelemregulációval; AKA = adaptív perfekcionista kontroll adaptív érzelemregulációval; NKN = nem perfekcionista kontroll kevés érzelemszabályozó stratégiával; $\mathrm{MKM}=$ maladaptív perfekcionista kontroll maladaptív érzelemregulációval. 


\section{MEGBESZÉLÉS}

Vizsgálatunkban fiatal versenyzốket hasonlítottunk össze ugyanazon oktatási intézményekbe járó nem élsportoló kortársaikkal a vonásszintú perfekcionizmus, a kognitív érzelemszabályozás és a szubjektív jóllét tekintetében. A nagy minta következtetéseinket kellôen megalapozhatja, azonban fontos megjegyezni, hogy a kutatás keresztmetszeti elrendezéssel dolgozott, ok-okozati viszonyokat nem képes és nem is volt célja feltárni.

Az élsportoló fiatalok - az elvártaknak megfelelóen - magasabb perfekcionizmuszszinttel jellemezhetốk, mint a nem élsportoló tanulók. Ez a különbség a magas belsố mércék (standardok) esetében a legerôteljesebben kifejezett. Mindez egybecseng azzal, hogy a versenyzés, a sport folyamatosan kimagasló teljesítményt követel (Weinberg és Gould, 2007). A versenyszerú sporttevékenységet folytató kamaszokat (sport) pályafutásuk kezdetén fokozottan nyomják az elvárások az egyre jobb eredmények elérésére. Ezek az elvárások részben kívülrôl származhatnak (edzók, család, csapattársak, kortársak hatása), de vélhetốen javarészt önazonosak. Az élsportoló fiatalok mintánkban átlagosan 7 éve vesznek részt a versenysportban, ami legtöbbjüknél iskolás éveik jelentốs részével átfed, tulajdonképpen beleszövôdik felnövekedésükbe. Két eriksoni pszichoszociális szakasz (Erikson, 2002) is érintett ebben a folyamatban: az egyik a kisiskoláskor idôszaka, amikor a teljesítmény, a kompetenciák megszerzése, a fizikai és a társas képességekben való hit kerül a fejlődés középpontjába. A másik érési szakasz a serdülőkor idôszaka, melynek középponti tényezôje a formálódó identitás. A sportág melletti elkötelezôdés segítheti a kamaszt a saját magáról mint egyedi személyrốl kialakított egységes kép felépítésében. Ezek mind olyan tényezôk, melyek meghatározók az élsportban, ugyanakkor a perfekcionista törekvések megerôsödésében is. Eredményeink támogatják azokat a korábbi vizsgálatokat, melyek amellett foglalnak állást, hogy a sportolói karrier fenntartásához elengedhetetlen tényezố a perfekcionizmus valamilyen szintû́ jelenléte, kifejezetten annak pozitív, adaptív oldala: a magasabb belsô standardok követése (pl. Stoeber, 2011; Gaudreau és Verner-Filion, 2012). Kutatásunkban azonban nem mértük fel az élsportoló kamaszok objektív teljesítménymutatóit, illetve sikereit. Ezt részben az indokolja, hogy a sportoló kamaszok különbözô sportágakban versenyeznek, az ott elért eredményeket nehéz kategorizálni és egybevetni. Késốbbi vizsgálatokban így érdemes lehet kitérni arra, hogy a mérhetố teljesítménymutatók, a sportbeli sikerek és kudarcok milyen kapcsolatban állnak a perfekcionizmus mutatóival (vö. pl. Wieczorek, Flett és Hewitt, 2003). Érdekes lehet továbbá olyan sportolókat is bevonni a perfekcionizmusvizsgálatokba, akik valamilyen ok miatt abbahagyták a versenysportot. Weinberg és Gould (2007) például a perfekcionizmust a kiégés alapvetố rizikófaktoraként azonosították fiatal élsportolók mintájában.

További eredményeink szerint az élsportolók - életmódjukkal és idôbeosztásukkal összefüggésbe hozhatóan - fizikálisan fittebbnek érzik magukat, és kevesebb idôt töltenek számítógép elốtt. Emellett a kontrollfiatalokhoz, azaz osztálytársaikhoz viszonyítva a nehéz, stresszes élethelyzeteken átlagosan kevesebb maladaptív érzelemszabályozó mód használatával igyekeznek túljutni. Különösen a negatív tapasztalatokkal való repetitív foglalkozás (rumináció) és a zavaró körülmények felnagyítása (katasztrofizálás) alacsonyabb szintû́ a versenyzốknél, ami elengedhetetlen lehet például a ku- 
darcok hatékony feldolgozásában. Lehetséges, hogy az élsportolók a versenysportban eltöltött éveik alatt a maladaptív érzelemregulációs módok csökkentésére, elhagyására szocializálódtak, melyet környezetük (pl. a sportszakmai személyzet tagjai) segíthetett. Érdekes lenne azt is változóként bevonni a további vizsgálatokba, hogy milyen támogatást (pl. sportpszichológus, az edzô vezetési stílusa) kap az élsportoló, ami érzelemszabályozását segíti. Ennek feltárására elsôként félig strukturált interjúk felvétele és elemzése lenne indokolt.

A sportolók egyértelmúen elkülönültek a nem sportoló kortársaiktól a szubjektív jóllétszintjüket tekintetbe véve: különösen a pszichológiai jóllét és a társas jóllét terén jeleztek magasabb értékeket. Azaz olyan jóllétösszetevôkben, mint az autonómia, az önelfogadás, a célok megléte, a személyes növekedés- vagy hatékonyságérzés (Keyes, 2002). Másrészt a társas/társadalmi közegben is hatékonyabban kiteljesednek: elfogadottabbnak, beágyazottabbnak és inkább olyannak érzik magukat, akik a társadalom fejlôdéséhez is képesek hozzájárulni (vö. Keyes, 2002). Ez az eredmény is konzisztens több korábbi kutatással (pl. Sagar és Stoeber, 2009; Gaudreau és Verner-Filion, 2012). Jelen vizsgálat azonban abban árnyaltabb az előzőeknél, hogy a szubjektív jóllét különbözô szegmenseit is figyelembe vette.

A fenti összehasonlítás - bár önmagában is informatív - számos tényezôt nem vesz figyelembe, ezért összetettebb statisztikai eljárással, látens klaszterezéssel tovább árnyaltuk a képet a két mintáról (élsportolók és kontroll) a perfekcionizmus és az érzelemszabályozás tekintetében. A mintából kirajzolódó csoportok speciális jellemzôit elemeztük, és nem a perfekcionizmus valamely elméleti modelljét teszteltük. A több mint ezerfős mintában - az élsportolói/nem élsportolói státuszt is figyelembe véve - hat értelmezhetô osztályt tudtunk elkülöníteni a perfekcionizmus és az érzelemszabályozás önjellemzései alapján: hármat a kontroll- és hármat az élsportolómintában. A 3-3 csoport - bár több hasonlóságot is mutatott (pl. maladaptív perfekcionista csoport megjelenése) - számos tekintetben eltért. Az élsportolók között ugyanis nem tudtunk nem perfekcionista csoportot azonosítani. Úgy tûnik, hogy az élsportban való megmaradás, kitartás és elôrejutás megköveteli a magas standardok jelenlétét, az elkötelezôdést a célok kiteljesítése iránt. Az nem mindegy, hogy ez milyen diszkrepanciamintázattal (a standardok és a teljesítmény között észlelt távolsággal) társul. Amennyiben magas a standardok és a teljesítmény között észlelt távolság, azaz a diszkrepancia és maguk a standardok is kifejezetten magasak, maladaptív folyamatok elôvételezhetôk. Ezt igazolja, hogy a maladaptív élsportolócsoport egyben több maladaptív érzelemreguláció-módot is alkalmaz, mint más perfekcionista élsportolói csoportok (adaptív perfekcionisták adaptív érzelemszabályozó stratégiákkal és adaptív perfekcionisták kevés érzelemregulációs technikával). Magas önvád-, rágódás- és katasztrofizálásértékeik azt sugallják, hogy a stresszteli szituációkon nem vagy csupán nagy érzelmi bevonódással, a helyzetekhez való alkalmazkodást gátló kognitív módszerek bevonásával tudnak túljutni. Ez az élsportolói csoport egyértelmúen veszélyeztetett például a kudarcélmények kezelésében akár a napi edzéseket, akár a versenyeket tekintve. Az ó kiszúrésük és egyéni vagy csoportos pszichológiai kezelésük nagyon fontosnak tûnik. A sportpszichológiai foglalkozás középpontjába náluk a magas belsố elvárások, a hibázástól való félelem, ezzel az önvád és a fokozott szorongás csökkentése, valamint a 
(lehetséges vagy valós) kudarchelyzetek felnagyításának és az azokon való visszatérô elidôzés leépítése kell hogy kerüljön.

A beavatkozások során lényeges az élsportolókon belül a két adaptív perfekcionista csoportot is elkülöníteni, hiszen az egyik csoport adaptív érzelemkezelési módokat használ, míg a másik alig alkalmaz érzelemszabályozó figyelmi vagy kognitív stratégiát. Az előbbi csoportnál - mely a szubjektív jóllét tekintetében a legkiemelkedóbb értékeket mutatja, így mentálisan a legegészségesebb csoportként azonosítható - a pszichológiai beavatkozás például a múködésmódok tudatosítására fókuszálhat. Csoportmunkában pedig kiváló modellt, s ezáltal segítséget nyújthatnak a sportoló vagy akár nem sportoló társaiknak. Ezt a csoportot kvalitatív eljárásokkal érdemes volna alaposabban is megvizsgálni, mert azzal olyan protektív faktorok - pl. gondolkodási, figyelmi, beállítódási, magatartási minták - azonosítására nyílna lehetôségünk, melyek a(z élsportoló) fiatalokat felkészíthetik a „valódi” pozitív, adaptív perfekcionizmus kialakítására és megélésére. A „minden tekintetben” adaptív élsportolók a magas teljesítményt igénylő stresszes helyzeteket (pl. téthelyzeteket) feltehetôen kiválóan oldják meg, kiegyensúlyozottak, az aktuális környezethez egymást erôsítô kognitív stratégiáikkal - perfekcionista beállítódásukkal és érzelemregulációs módjaikkal - jól alkalmazkodnak. Azoknál az adaptív perfekcionista élsportolóknál pedig, akik az érzelemszabályozás terén alacsony készségekkel bírnak, az adaptív érzelemszabályozás módjait érdemes erôsíteni. Ez a versenyszerüen sportoló csoport vagy elnyomhatja érzéseit, és így kevés kognitív emócióregulációs stratégiára van szüksége, vagy a pozitív perfekcionista múködésmódnak (magas törekvésszint alacsonyabb perfekcionista önkritikával) köszönhetốn a nehéz élethelyzetekhez is jól alkalmazkodik, pozitív érzelmeik (képességeikben való bizalom, elégedettség önmagukkal) átsegítik ôket a nehézségeken. Ennek további vizsgálata még várat magára.

A nem élsportolók körében az elméleti alappal bíró „adaptív perfekcionista - maladaptív perfekcionista - nem perfekcionista” hármas felosztás (Stoeber és Otto, 2006) egyértelmúen kirajzolódott. A látens klaszterelemzéssel nyert természetes csoportok megerôsítik azt az elméletet (pl. Stoeber, 2011) és a változóorientált megközelítésen nyugvó eredményeket (pl. Rice és Ashby (2007), melyek szerint maladaptív perfekcionizmus nem létezik magas személyes standardok nélkül. Vagyis azok, akik magas diszkrepanciával jellemezhetôk alacsony perfekcionista törekvésszint mellett, a nem perfekcionisták közé sorolhatók. Ez ellentmond a perfekcionizmus $2 \times 2$-es modellje (Gaudreau és Thompson, 2010) által felvázoltaknak.

Érdekes jelenség, hogy a nem perfekcionista kontrollcsoport általában milyen kevés érzelemregulációs stratégiát mozgósít a mindennapjaiban. Felvetôdik a kérdés, mi állhat ennek hátterében. Az egyik magyarázat az lehet, hogy amennyiben nincs a perfekcionista beállítódásból fakadó érzelmi nyomás, akkor csak elenyészô mértékú kognitív érzelemszabályozó folyamatra van szükség. Az alacsony törekvésszint pedig kevesebb teljesítmény- vagy versenyhelyzetet teremt. Az is lehetséges, hogy a nem perfekcionisták eleve stresszmentességre törekednek, mert érzelmeiket nehezen kezelik, így a standardok és elvárások alacsony szintje mellett érzelmi hôfokuk és az érzelmeket szabályozó technikák használata is visszafogottabb.

Kiemelendô, hogy mind az élsportoló-, mind pedig a kontrollmintában a legtöbb kamasz az adaptív perfekcionisták jellemzóivel bír. Ugyanakkor azt is meg kell je- 
gyezni, hogy az élsportolók közel negyede, a kontrollkamaszoknak pedig 30\%-a maladaptív perfekcionista vonásokkal jellemezhetô, ami rizikófaktorként értékelhetô számos negatív mentálisegészség-mutató tekintetében (pl. Hamachek, 1978; Flett és Hewitt, 2002).

Vizsgálatunk fontos eredménye, hogy a kirajzolódó perfekcionista csoportok között a mentális egészség tekintetében jelentôs különbségek látszanak. A rendszeres, versenyszerû sport egyértelmú védőfaktorként körvonalazódik: a legmagasabb szubjektívjóllét-szinttel az adaptív perfekcionista és adaptív érzelemszabályozással jellemezhetó élsportolók rendelkeznek. Különösen igaz ez az eudaimonikus, azaz a nem pusztán a boldogsággal, de a humán potenciál kibontakoztatásával is összefüggó (Keyes, 2002) jóllétterületekre, a pszichológiai és a társas jóllétre. A kutatási adatok megerôsítik, hogy az élsport a maga keretrendszerével, az abban elért teljesítménnyel, élményekkel abban az esetben hat rendkívül pozitívan a mentális egészségre, ha az alkalmazkodást segítô perfekcionista mintázattal és érzelemszabályozással társul. Feltehetôen a három tényezô egymást erôsítô folyamat, és az ok-okozati viszonyok körkörös megerôsítésen alapulnak. A maladaptív perfekcionizmus vizsgálatunkban is alacsony jóllétszinttel asszociálódott, ami a kapuja lehet a mentális betegségtüneteknek (pl. Keyes, 2002). Ennek alapján felvetôdik, hogy a maladaptív perfekcionista és érzelemszabályozó kogníciók a szubjektív jóllét, például az énhatékonyság és az autonómia csökkentésén keresztül vezetnek pszichés tünetekhez.

\section{KÖVETKEZTETÉSEK}

Vizsgálatunkban a látens klaszterelemzésen alapuló eredményekkel állást tudtunk foglalni a szakirodalomban versengó perfekcionizmusmodellek érvényessége tekintetében. Kutatásunk azt az elméleti irányt erôsíti (pl. Stoeber, 2011), amely szerint a maladaptív perfekcionizmus magas személyes standardok nélkül nem definiálható kategória. Ezzel tovább tudtuk árnyalni a perfekcionizmuskutatások szerteágazó és gyakran paradox képét - élsportolói mintán is. További fontos eredmény, hogy a versenyszerúen sportoló és az ilyen módon nem sportoló fiatalok körében a perfekcionista múködésmód alapján jól körülhatárolható és jellemezhetô csoportok azonosíthatók az érzelemszabályozás és a szubjektív jóllét terén. Míg az adaptív perfekcionista atléták adaptív érzelemregulációs stratégiák aktív alkalmazásával a szubjektív jóllét optimumán állnak, addig a maladaptív perfekcionista kontrollba tartozó serdülốk a pszichés „hervadás” (languishing, Keyes, 2002) jegyeit mutatják alacsony jóllétértékeikkel. Mindez körvonalazza a beavatkozások fókuszát a maladaptív perfekcionista vonásokat mutató fiatalok (sport)pszichológiai ellátásában, mint például a rigid és/vagy irreális perfekcionista standardok és intruzív, repetitív gátló gondolatok kognitív viselkedésterápiás leépítését.

\section{KÖSZÖNETNYILVÁNÍTÁS}

Reinhardt Melindát a Nemzeti Kutatási, Fejlesztési és Innovációs Hivatal - NKFIH a PD 128332 számmal elnyert pályázat keretében támogatja. 


\section{IRODALOM}

Aldea, M. A., \& Rice, K. G. (2006). The role of emotional dysregulation in perfectionism and psychological distress. Journal of Counseling Psychology, 53, 498-510.

Andrews, D. M., Burns, L. R., \& Dueling, J. K. (2014). Positive perfectionism: Seeking the healthy "should", or should we? Open Journal of Social Sciences, 2, 27-34.

Brady, A., Grenville-Cleave, B. (2018). Contemporary findings about the value of well-being and positive psychology in sport and physical activity settings. In Brady, A., \& Grenville-Cleave, B. (Eds), Positive Psychology in Sport and Physical Activity (pp. 35-47). London and New York: Routledge.

Burns D. D. (1980). The perfectionist's script for self-defeat. Psychology Today, 34-51.

Burns, L. R., \& Fedewa, B. A. (2005). Cognitive styles: Links with perfectionistic thinking. Personality and Individual Differences, 38, 103-113.

Cohen, J. (1992). A power primer. Psychological Bulletin, 112, 155-159.

Dunn, J. G. H., Causgrove Dunn, J., \& Syrotuik, D. G. (2002). Relationship between multidimensional perfectionism and goal orientations in sport. Journal of Sport Eं Exercise Psychology, 24, 376-395.

Erikson, E. H. (2002). Gyermekkor és társadalom. Budapest: Osiris.

Flett, G. L., \& Hewitt, P. L. (2002). Perfectionism and maladjustment: An overview of theoretical, definitional, and treatment issues. In Hewitt, P. L., \& Flett, G. L. (Eds), Perfectionism: Theory, research, and treatment (pp. 5-31). Washington, DC: American Psychological Association.

Flett, G. L., \& Hewitt, P., L. (2005). The perils of perfectionism in sports and exercise. Current Directions in Psychological Science, 14, 14-18.

Flett, G. L., \& Hewitt, P. L. (2006). Positive versus negative perfectionism in psychopathology: A comment on Slade and Owens's dual process model. Behavior Modification, 30, 472-495.

Flett, G. L., Hewitt, P. L., Blankstein, K. R., \& Gray, L. (1998). Psychological distress and the frequency of perfectionistic thinking. Journal of Personality and Social Psychology, 75, 1363-1381.

Frost, R. O., \& Henderson, K. J. (1991). Perfectionism and reactions to athletic competition. Journal of Sport and Exercise Psychology, 13, 323-335.

Frost, R. O., Trepanier, K. L., Brown, E. J., Heimberg, R. G., Juster, H. R., Makris, G. S., \& Leung, A. W. (1997). Self-monitoring of mistakes among subjects high and low in perfectionistic concern over mistakes. Cognitive Therapy and Research, 21, 209-222.

Garnefski, N., \& Kraaij, V. (2006). Cognitive emotion regulation questionnaire - development of a short 18-item version (CERQ-short). Personality and Individual Differences, 41, 1045-1053.

Garnefski, N., Kraaij, V., \& Spinhoven, P. (2001). Negative life events, cognitive emotion regulation and depression. Personality and Individual Differences, 30, 1311-1327.

Gaudreau, P., \& Thompson, A. (2010). Testing a 2x2 model of dispositional perfectionism. Personality and Individual Differences, 48, 532-537.

Gaudreau, P., \& Verner-Filion, J. (2012). Dispositional perfectionism and well-being: A test of the 2 X 2 model of perfectionism in the sport domain. Sport, Exercise, and Performance Psychology, 1(1), 29-43.

Hall, H. K., Jowett, G. E., \& Hill, A. P. (2014). Perfectionism: The role of personality in shaping an athletes' sporting experience. In Papaioannou, A. G., \& Hackfort D. (Eds). Routledge Companion to Sport and Exercise Psychology. London: Routledge, 152-168.

Hall, H. K., Kerr, A. W., \& Matthews, J. (1998). Precompetitive anxiety in sport: The contribution of achievement goals and perfectionism. Journal of Sport \& Exercise Psychology, 20, 194-217.

Hamachek, D. E. (1978). Psychodynamics of normal and neurotic perfectionism. Psychology: A Journal of Human Behavior, 15, 27-33. 
Keyes, C. L. M. (2002). The Mental Health Continuum: From Languishing to Flourishing in Life. Journal of Health and Social Behavior, 43(2), 207-222.

Keyes, C. L. M. (2006). Mental Health in Adolescence: Is America's Youth Flourishing? American Journal of Orthopsychiatry, 76(3), 395-402.

Keyes, C. L. M. (2009). The Nature and Importance of Positive Mental Health in America's Adolescents. In Gilman, R., Huebner, E. S., \& Furlong, M. J. (Eds). Handbook of Positive Psychology in Schools (pp. 9-23). New York: Routledge.

Koivula, N., Hassmén, P., \& Fallby, J. (2002). Self-esteem and perfectionism in elite athletes: Effects on competitive anxiety and self-confidence. Personality and Individual Differences, 32, $865-875$.

Lamers, S. M. A., Westerhof, G. J., Bohlmeijer, E. T., Ten Klooster, P. M., \& Keyes, C. L. M. (2011). Evaluating the Psychometric Properties of the Mental Health Continuum-Short Form (MHC-SF). Journal of Clinical Psychology, 67(1), 99-110.

Miklósi, M., Martos, T., Kocsis-Bogár, K., \& Perczel Forintos, D. (2011). A Kognitív Érzelem-Reguláció Kérdôív magyar változatának pszichometriai jellemzői. Psychiatria Hungarica, 26(2), 102-111.

Muthén, L. K., \& Muthén, B. O. (1998-2017). Mplus User's Guide. Eighth Edition. Los Angeles, CA: Muthén \& Muthén.

Nunnually, J. C. (1978). Psychometric Theory. 2nd edition. New York: McGraw-Hill.

Oláh, A. (2012). A pszichológia napos oldala. In Oláh A. (szerk.), A pozitío pszichológia világa (pp. 3-11). Budapest: Akadémiai Kiadó.

Oláh, A., \& Kapitány-Fövény, M. (2012). A pozitív pszichológia tíz éve. In Oláh, A. (szerk.), A pozitív pszichológia világa (pp. 19-45). Budapest: Akadémiai Kiadó,

Reinhardt, M. (2013). Mentális egészség és tünetképzés összefüggései a családi múködéssel serdülóknél. Doktori (PhD-) disszertáció. Budapest: ELTE PPK Pszichológiai Doktori Iskola.

Reinhardt M. (2014). Szubjektív jóllétünk érzelmi, pszichológiai és társas mozaikdarabkái A mentális egészség kétkontinuum-modellje. In Fülöp J., Mirnics Zs., Vassányi M. (szerk.), Kapcsolatban - Istennel és emberrel (pp. 15-31). Budapest: L'Harmattan Kiadó.

Reinhardt, M., Tóth, L., \& Rice, K. G. (2018). Perfectionism reflected in emotion regulation and mental health among young elite athletes and controls. 39th STAR Conference of the Stress and Anxiety Research Society, Lublin, Lengyelország, 2018. július 10-13.

Reinhardt, M., Rice, K. G., \& Tóth, L. (2019). Latent profiles of perfectionism, mental health and stress in American and Hungarian undergraduates. 40th STAR Conference of the Stress and Anxiety Research Society, Palma de Mallorca, Spanyolország, 2019. július 9-12.

Rice, K. G., \& Ashby, J. S. (2007). An efficient method for classifying perfectionists. Journal of Counseling Psychology, 54, 72-85.

Rice, K. G., Richardson, C. M. E., \& Tueller, S. (2014). The Short Form of the Revised Almost Perfect Scale. Journal of Personality Assessment, 96(3), 368-379.

Rice, K. G., Gilman, R., Tóth, L., Hong, J., Taber, Z. B., \& Reinhardt, M. (2018). Perfectionism in Hungarian and American Adolescents. 30th Association for Psychological Science Annual Convention, San Francisco, USA, 2018. május 24-27.

Sagar, S. S., \& Stoeber, J. (2009). Perfectionism, fear of failure, and affective responses to success and failure: The central role of fear of experiencing shame and embarrassment. Journal of Sport \& Exercise Psychology, 31, 602-627.

Stoeber, J. (2011). The dual nature of perfectionism in sports: Relationships with emotions, motivation, and performance. International Review of Sport and Exercise Psychology, 4, 128-145.

Stoeber, J. (2012). Perfectionism and performance. In Murphy, S. M. (Ed), The Oxford handbook of sport and performance psychology (pp. 294-306). New York: Oxford University Press. 
Stoeber, J., \& Becker, C. (2008). Perfectionism, achievement motives, and attribution of success and failure in female soccer players. International Journal of Psychology, 43, 980-987.

Stoeber, J., \& Otto, K. (2006). Positive concepcions of perfectionism: Approaches, evidence, challenges. Personality and Social Psychology Review, 10, 295-319.

Stoeber, J., Otto, K., Pescheck, E., Becker, C., \& Stoll, O. (2007). Perfectionism and competitive anxiety in athletes: Differentiating striving for perfection and negative reactions to imperfection. Personality and Individual Differences, 42, 959-969.

Terry-Short, L. A., Owens, R. G., Slade, P. D., Dewey, M. E. (1995). Positive and negative perfectionism. Personality and Individual Differences, 18(5), 663-668.

Weinberg, R. S., \& Gould, D. (2007). Foundations of Sport and Exercise Psychology. 4th edition. Champaign, IL, US: Human Kinetics.

World Health Organization (WHO) (2001). Declaration of Helsinki. Bulletin of the World Health Organization, 79(4), 373-374.

Wieczorek, J., Flett, G. L., \& Hewitt, P. L. (2003). Dimensions of perfectionism, anxiety, and coping in successful versus unsuccessful golfers. Unpublished manuscript, York University, Toronto, Ontario, Canada.

Williams, G. A., \& Kibowski, F. (2015). Latent Class Analysis and Latent Profile Analysis. In Jason, L. A., \& Glenwick, D. S. (Eds), Handbook of Methodological Approaches to Community-Based Research: Qualitative, Quantitative, and Mixed Methods (pp. 143-152). New York: Oxford University Press.

Zarghmi, M., Ghamary, A., Shabani, S. E. H. S., \& Varzaneh, A. G. (2010). Perfectionism and achievement goals in adult male elite athletes who compete at the national level and above. Journal of Human Kinetics, 26, 147-155. 


\title{
POSITIVE MENTAL HEALTH OF PERFECTIONISTS - PATTERNS OF PERFECTIONISM, EMOTION REGULATION AND SUBJECTIVE WELL-BEING AMONG YOUNG ELITE ATHLETES
}

\author{
REINHARDT, MELINDA - TÓTH, LÁSZLÓ - KENNETH, G. RICE
}

Background and Objectives: Adaptive and maladaptive perfectionism are in different connections with several characteristics which are important in sport performance, therefore the main aim of our study was to identify and characterize latent classes of perfectionism and emotion regulation strategies in connection with positive mental health in a large young elite athlete sample and controls.

Methods: 744 young elite athletes $(60.2 \%$ boy, mean age $=16.83, S D=1.39)$ and 591 controls $(50.8 \%$ boy, mean age $=16.91, S D=1.65)$ took part in the research. The questionnaire booklet included the Short Form of the Revised Almost Perfect Scale (Rice et al, 2014), the short version of the Cognitive Emotion Regulation Questionnaire (Garnefski \& Kraaij, 2006), and the Adolescent Mental Health Continuum-Short Form (Keyes, 2006).

Results: Using Latent Profile Analysis we could reveal a well-interpreted 3-class solution in both samples with good fit indices. Among non-athletes the outlined 3 classes are parallel with several former theoretical and empirical results: adaptive, maladaptive, and non-perfectionists emerged. In the elite athlete sample two adaptive groups and a maladaptive were delineated. One of the adaptive perfectionist athlete group can be featured by adaptive emotion regulation, while the other can be described with low use of emotion regulation strategies. Of the six latent classes the elite athlete group with adaptive perfectionism and adaptive emotion regulation has the highest level of global, emotional, psychological, and social well-being.

Conclusions: Detected latent classes highlight that mechanisms of perfectionism accompany with different styles of emotion regulation and these patterns are in close relationship with subjective well-being.

Keywords: adaptive and maladaptive perfectionism, emotion regulation strategies, positive mental health, elite athletes

A cikk a Creative Commons Attribution 4.0 International License (https://creativecommons. org/licenses/by/4.0) feltételei szerint publikált Open Access közlemény, melynek szellemében a cikk bármilyen médiumban szabadon felhasználható, megosztható és újraközölhetô, feltéve, hogy az eredeti szerzố és a közlés helye, illetve a CC License linkje és az esetlegesen végrehajtott módosítások feltüntetésre kerülnek. (SID_1) 